\title{
Surficial Geology of the Newly Annexed Area of Kirkland, Washington King County, USA
}

\author{
Justin L Brooks
}

A report prepared in partial fulfillment of the requirement for the degree of

Master of Science

Earth and Space Sciences: Applied Geosciences

University of Washington

June 2017

Project Mentor:

Kathy Troost University of Washington

Internship Coordinator:

Kathy Troost

Reading Committee:

Kathy Troost

Stephen Walters

MESSAGe Technical Report 055 
(C)

Justin L Brooks 


\section{Geologic Map of Kirkland, Washington}

Justin L Brooks

\section{EXECUTIVE SUMMARY}

The 2014 Oso landslide brought nationwide attention to the geologic hazards of Washington State, impelling City of Kirkland officials to create a new geologic map of recently annexed areas and update prior 2010 geologic map products to protect the community. Geologic hazards within the City include but are not limited to landsliding and earthquake-induced ground failure. City engineers, planners, and emergency managers will use these products for assessing and mitigating hazards, prioritizing facility upgrades, and other city projects. Also, these products will allow experts to address risks and make recommendations on construction projects developed within hazard areas according to the City's zoning code. An updated geologic map will also allow interested persons, including students and Kirkland residents the opportunity to learn about local geology. The work is necessary to upgrade the City's Growth Management Act (GMA) products. This information is useful to determine areas that can support high-density growth in a rapidly growing city. My map was compared to Minard's 1983 surficial geology map of the area. Additionally, my map extends the area of the Troost and Wisher 2010 map.

Kirkland's geologic history plays a major role in shaping the city's landscape. Multiple glacial advances and retreats left a tangle of silt, sand and gravel deposits of various densities. The annexation area consists of two broad upland plateaus divided by glacially derived channels. The surficial geology of these plateaus is a blanket of Vashon till overlying a thick layer of Vashon advance outwash. Exposed in some areas is a deposit of Vashon Lawton Clay. The clay is very stiff to hard and marks the transition from non-glacial to earliest glacial time. Pre-Vashon deposits are exposed in some areas. The channels are lined with Vashon recessional outwash and recessional lacustrine deposits. The recessional lake deposits discovered were recessional Lake Bretz (120-15 feet), Lake Totem (160-180 feet) and Lake Juanita (50-90 feet). Additionally, paleotopography is found on the eastern slopes of the upland plateaus. Landslides are abundant on the steep nonconsolidated slopes.

To create the 2017 map, I prepared base maps with the 2016 LIDAR data, conducted new field mapping, managed the input of geotechnical data into the GeoMap NW database, and completed a geomorphic analysis. Datapoints used to draw geologic unit polygons consisted of more than 250 field stations and more than 2000 subsurface investigations. Field data were acquired by interpreting excavations at construction sites and by exploring area gullies to find outcrops. Borehole logs, acquired from several different entities, were the main source of geologic data for the map. 
The main limitation to this project was the lack of exposures in the well-established neighborhoods of the annexation area. Subsurface reports filled in much of the data gaps that existed due to this limitation. However, areas with no surficial geologic information exist throughout the mapping area, which led to interpolating geology to complete the map. 


\section{Table of Contents}

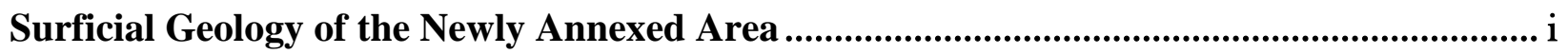

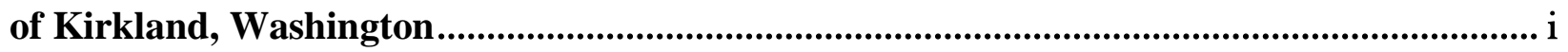

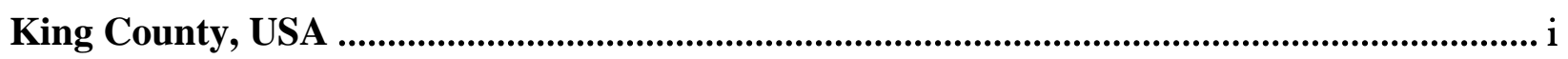

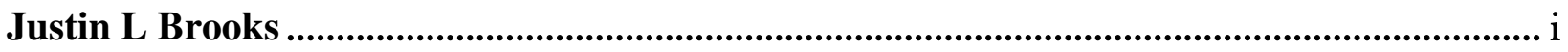

EXECUTIVE SUMMARY …......................................................................................... ii

LIST OF FIGURES.........................................................................................................

LIST OF TABLES AND CHARTS ....................................................................................

ACKNOWLEDGEMENTS ................................................................................................ii

INTRODUCTION

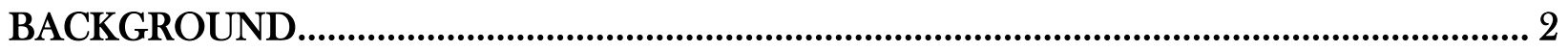

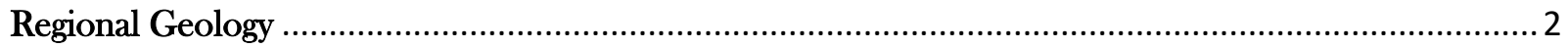

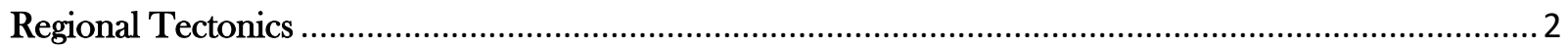

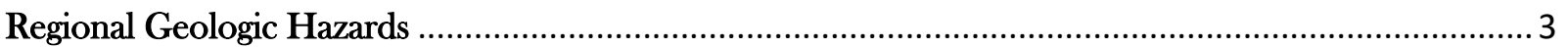

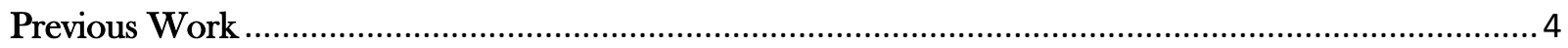

Deliverables for Kirkland, Washington ................................................................................. 4

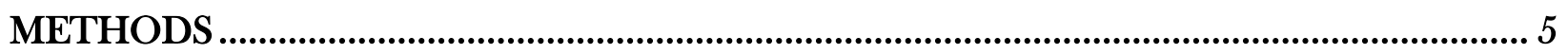

Preliminary Base Maps

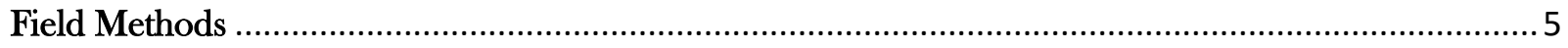

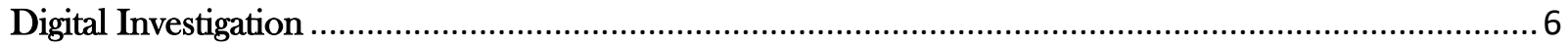

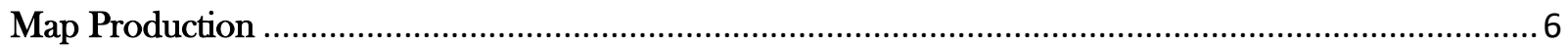

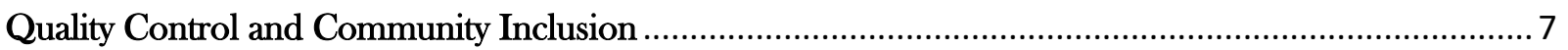

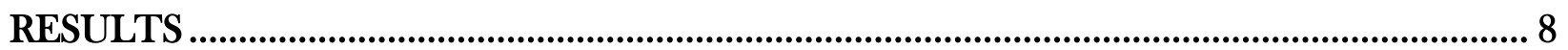

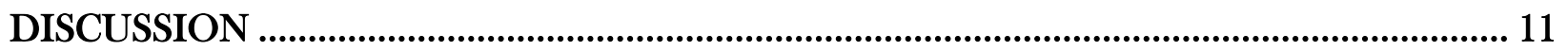

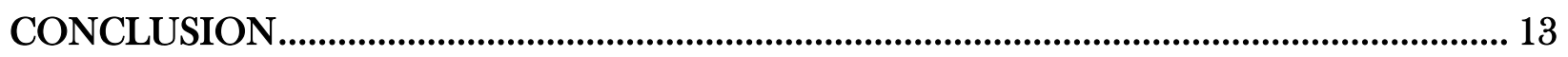

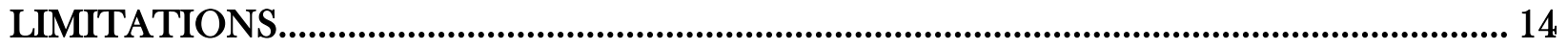

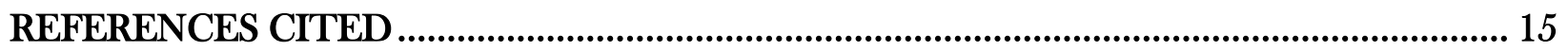

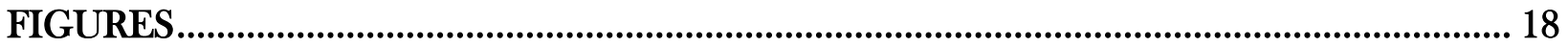




\section{LIST OF FIGURES}

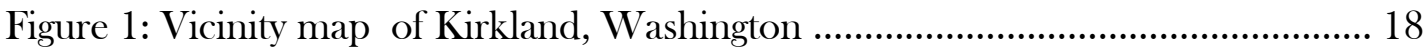

Figure 2: Illustrates the stratigraphic relationships ................................................... 19

Figure 3: Topographical lineaments outlined by McCormack and Troost ................ 20

Figure 4: I extrapolated fault traces from Washington Geological Survey................ 21

Figure 5: Mace and Keranen (2012) illustrate ...................................................... 22

Figure 6: Troost and Wisher, 2010 .................................................................. 23

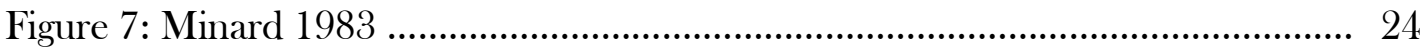

Figure 8: : A percent slope map (top) and a hillshade model bottom) .................. 25

Figure 9: A digital elevation model (DEM) of Kirkland ...................................... 26

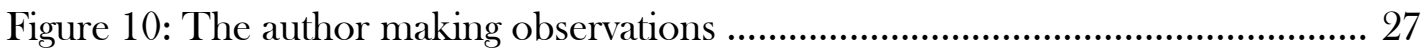

Figure 11: The author contemplating an outcrop ............................................... 28

Figure 12: This map of the annexation area shows my field stations ...................... 29

Figure 13: 1:12,000 scale Surficial geology map of Kirkland ................................ 30

Figure 14: 1:12,000 scale surficial geology map of Kirkland's annexation area ........ 31

Figure 15: Image showing glacially formed broad recessional channels .................. 32

Figure 16: Ground surface profiles displaying elevation changes ........................... 33

Figure 17: The ground surface elevation profile illustrates .................................... 34

Figure 18: Percent slope map showing extent of ............................................... 35

Figure 19: A photograph of the initiation point of a recent shallow landslide ......... 36

Figure 20: Photograph of scour and debris ....................................................... 37

Figure 21: The landslide ran up the opposite valley wall ..................................... 38

Figure 22: The red box illustrates the location .................................................. 39

Figure 23: Comparing the two surficial geology maps ....................................... 40 


\section{LIST OF TABLES AND CHARTS}

Table 1: Breakdown of Datapoints ................................................................... 41

Table 2: Comparing the Total Area of Geologic Units ....................................... 42

Chart 1: Comparison of Total Area of Geologic Units ...................................... 43

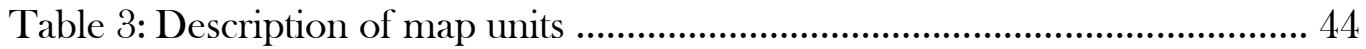




\section{ACKNOWLEDGEMENTS}

There are many people to thank for making this project possible. First and foremost, I want to thank my darling wife, Sonja, for her support, encouragement, faith and patience. This is all her fault.

Kathy Troost is my go to gal for on the ground geology and job hunting. We have had a time in the field. Thank you for pushing me to be the best geologist. It has been a pleasure to work with you.

Thank you, Juliet Crider for having all the answers.

A very special thank you to Steven Walters, Alison Duvall, J Michael Brown, and Brian Collins for their dedication to the MESSAGe program and for their unwaning dedication to our success.

Special Thanks to Harvey Greenberg for your GIS support.

Brian Atwater and Charlotte Schreiber, thank you so much for being awesome.

So many other people have helped me get to this point and shaped me into the geologist that I have become:

Roger Buick

George Bergantz

Jody Bourgeois

Darrel Cowen

Terry Swanson

Noéll Bernard-Kingsley

Drew Gorman-Lewis
Michael McCarthy

Katharine Huntington

Bruce Nelson

Gerard Roe

John Stone

John Vidale

I would like to thank all the members of my MESSAGe cohort for suffering this endeavor with me and always being there through thick and thin.

Unwavering gratitude to my Data Entry Team: James Kohn, Lauren Thompson, Maddy Hummer, Hannah Allen, and Devin Maloney. Without their work, this project could not happen.

In addition, I would like to thank the crew at the city of Kirkland for the many hours and emails they put into making this project a success: Paul Stewart, Jeremy McMahan, Jenny Gaus, Karl Johansen and Wes Ayers. 


\section{INTRODUCTION}

Many factors spurred the production of a new geologic map for the City of Kirkland (City). The 22 March 2014 Oso landslide, which claimed the lives of 43 people, was the deadliest landslide in continental US history (Wartman et al., 2016). This event brought nationwide attention to the geologic hazards of Washington State, impelling City of Kirkland officials to take appropriate action to protect the community. The Kirkland landscape is prone to many geologic hazards that are a direct result of its depositional environment. Geologic hazards within the city include, but are not limited to, landsliding and earthquake-induced ground failure, such as liquefaction. An updated geologic map will also allow interested persons, students and Kirkland residents the opportunity to learn about the local geology. This mapping project is the direct result of Kirkland City Council's proactive management and forward thinking regarding the safety of its citizens and minimizing risks to property and life.

This report pertains to the geologic map of the newly annexed portion of Kirkland, Washington. The report includes descriptions of map units. Troost and Wisher completed a geologic map for the City in 2010. Since that time, the City annexed seven square miles, essentially doubling its size (City of Kirkland, 2016). This project extends the area of the 2010 map into the newly annexed regions. Mapping began in July 2016 and continued until May 2017. The work is necessary to upgrade the City's Growth Management Act (GMA) products. City engineers, planners, and emergency managers will use these products for hazard assessment and mitigation, prioritizing facility upgrades and other city projects. Also, these products will allow experts to address risks and make recommendations on construction projects developed within hazard areas according to the city's zoning code. The map provides valuable information for land use planning, permitting, and decision-making. This information is useful to determine areas that can support high-density growth in a rapidly growing city.

Kirkland lies east of Seattle, is bordered on the north by approximately NE 145th St, on the east by approximately 132nd Ave NE, on the west by Lake Washington, and extends south to HW 520 (Figure 1). The City of Kirkland annexed the Finn Hill (7.954 mi²), North Juanita and Kingsgate (2.317 $\left.\mathrm{mi}^{2}\right)$ areas effective June 1, 2011. The locations of these regions are just north of NE 116th Street between Lake Washington to the west and the City of Redmond to the east. Previously, the city annexed the Bridle Trails area east of 132nd Ave NE between NE 60th Street to the south and Old Redmond Rd to the north. 


\section{BACKGROUND}

\section{Regional Geology}

Understanding the geologic history of the Puget Lowland is critical to interpretations of the geologic deposits in the area. From the north, Pleistocene glaciers advanced and retreated at least six times in the last 2.4 m.y. (Easterbrook et al., 1967, Booth et al., 2003, Troost et al., 2008). The most recent Puget Lowland glaciation, the Puget Lobe of the Vashon Stade of the Fraser glaciation, reached its maximum 17,590 cal yrs B.P. (Porter and Swanson, 1998). As the Puget Lobe advanced into the region, bounded on the west by the Olympic Peninsula and to the east by the Cascade Mountains, the lobe blocked the Puget Sound inlet at the Strait of Juan de Fuca. This blockade created a lake whose level was dictated by the elevation of the Black Lake spillway. This lowland lake provided the setting for the widespread deposition of a laminated lacustrine clay layer locally known as the Lawton Clay (Qvlc) (Mullineaux et al., 1965). The Lawton Clay filled most of the lowlying area. As the Puget Lobe continued to advance southward, a thick layer of sand several tens to over one hundred feet thick was deposited across the region, above the Lawton Clay. This advance outwash sand (Qva) is known as the Esperance Sand (Armstrong et al., 1965). Finally, deposited like a blanket above the sand layer lies the Vashon till (Qvt), a compact poorly sorted nonstratified deposit. Glacial Lake Russell and later Glacial Lake Bretz, which filled to 134 feet and 100 feetrespectively (Porter and Swanson, 1998, Booth et al., 2003) were created with the retreat of the glacier from the lowland. The height of the spillways dictated the lake elevations. The glaciers dumped sand and gravel as recessional outwash (Qvr) during retreat from the area. Since the retreat of the glaciers, organic soils have developed where the glaciers previously removed or buried them, colluvium (Qmw) deposition on the slopes has continued, and lakes and rivers have formed further changing the landscape. Figure 2 presents a conceptualization of the glacial stratigraphy found in Kirkland.

\section{Regional Tectonics}

The active tectonics of the Puget Sound area are an ever-present threat to Kirkland and the region. In addition to the subduction earthquakes that threaten the region (Atwater, 1987), shallow crustal faults pose a seismic hazard to the large population. The Seattle Fault Zone (SFZ) and the Southern Whidbey Island Fault system (SWIF) have been the focus of much of the research efforts into these types of shallow earthquakes (Johnson and others, 1994, 1996, 1999). Even though Kirkland is included as part of the Seattle basin, and while these systems threaten the regions that they intersect, the SFZ passes south of Kirkland and the SWIF passes to the north of Kirkland. However, work by McCormack and Troost (2015) indicate possible SWIF involvement in Kirkland tectonics. Their findings identify parallel to subparallel linear magnetic anomalies and topographic lineaments that may intersect Kirkland city limits (Figure 3). Sherrod et. al 2008 described the methods for extending the SWIF which is hidden beneath development and vegetation. I extended inferred fault traces from Washington Geological Survey and topographical 
lineaments from McCormack and Troost to illustrate the importance of a new geologic map should faults be discovered extending to the City (Figure 4). The extrapolated lines in no way indicate the presence of faults in those areas, only a possibility of faults if the fault traces and lineaments extend past their inference. Additionally, newly discovered northeastward and northwestward trending shallow crustal fault systems may be potential earthquake hazards capable of M7 quakes (Mace and Keranen, 2012). Mace and Keranen point out that, like most of the other regional fault systems, these systems are probably much bigger than what they have mapped. These faults, when the directional trends are extrapolated, trend through Kirkland (Figure 5). Finally, the third type of quake mechanism, Wadati-Benioff Zone or deep earthquakes affects the region. These deep earthquakes originate over 400 miles deep within the subducting crustal slab and are capable of M7 quakes. The regional effects of an earthquake originating from any of these discussed mechanisms are highly dependent on the geology of the area, which makes this new map crucial.

\section{Regional Geologic Hazards}

The Kirkland landscape is prone to many geologic hazards that are a direct result of the depositional environment, glacial stratigraphy, regional tectonics, high precipitation rates and steep slopes. Landslides, liquefaction, peat settlement and subaqueous landsliding are a few of the hazards Kirkland faces. First, Qvt is not continuous in the area and contains discontinuities throughout, which allows surface water to reach the Qva layer. Water easily moves down through the sand layer (Qva) until it reaches a permeability contrast such as that at the relatively impermeable clay layer (Qvlc). At the clay layer, water begins moving laterally until it intersects a hillside. Tubbs identifies the Esperance Sand/Lawton Clay contact as the zone of greatest landslide hazard (1974). The contact is also exposed in steep-sided gullies. Tubbs and other researchers also maintain that a high water table and a period of intense rain are necessary to produce landslides (Tubbs, 1974 and Chleborad et al., 2006). These factors contribute to increased slope material weight and increased pore water pressure. Additionally, water adds a buoyancy force that further destabilizes slopes. Kirkland has many areas that are susceptible to mass movement and landslides with steep slopes along Lake Washington and several steep-sided gullies, which are densely developed. Next, the saturated to partially saturated loose soils found in the region are susceptible to liquefaction when combined with a seismic event. Liquefaction causes these soils to substantially lose strength and stiffness, essentially becoming liquid. Third, the presence of large areas of peat in the region makes subsidence by peat compression and decomposition an issue. Building on peat areas increases the effective stress on the waterlogged organic material and decreases pore space, which in turn causes compression and subsequent subsidence (Koster, et al., 2016). Finally, subaqueous landslides can originate on the delta slopes of major rivers or on steep submarine slopes that are the result of glacial action. Subaqueous landsliding occurs when these lake slopes fail and have the ability to create a tsunami. These various geologic hazards illustrate the need for quality geologic maps of the area. 


\section{Previous Work}

GeoMap NW at the University of Washington Earth and Space Sciences Department completed a high-resolution geological map and database of subsurface information for the City of Kirkland in 2010, whose data forms the base of my mapping project (Troost and Wisher, 2010). The prior work utilized more than 3000 data points and 1050 documents as well as approximately 350 field sites to create the 2010 map (Troost and Wisher, 2010) (Table 1) (Figure 6). Before the 2010 Kirkland map by GeoMapNW, a 1:24,000 - scale map was completed in 1983 (Minard, 1983) (Figure 7). The 1983 map displays only seven geologic units in the area compared with the 2010 map, which shows 36 (Troost and Wisher, 2010). My 2017 map incorporates a significant amount of the previous work done by Troost and Wisher at GeoMap NW.

\section{Deliverables for Kirkland, Washington}

This project created a geologic map for the newly annexed areas. Field work, data mining, and database compilation were required to produce the map. A technical memo, metadata, and a one-page fact sheet for the public are additional products of this work, included with the map. In addition to the new annexation geologic map, I provided updates for the existing geologic map that was produced by Troost and Wisher (2010). 


\section{METHODS}

To complete a new 1:12,000-scale geologic map of Kirkland's recently annexed areas and to update the existing geologic coverage, I prepared base maps with the 2016 LiDAR data, conducted new field mapping, managed the population of geotechnical data into the GeoMap NW database, and completed a geomorphic analysis.

\section{Preliminary Base Maps}

A consortium of regional municipalities in 2016 acquired new LiDAR data with the intention of updating map products using best available science. This LiDAR data has a spatial density eight times that of previous LiDAR data. A high return density equates to higher resolution maps. The high resolution allows for better identification of landforms such as historic landslides and other geomorphic features. This LiDAR better resolves the hummocky terrain that is associated with landslides. A hillshade model and a slope map based on percent slope were initially created from the LiDAR as base maps over which to develop shapefiles associated with the geologic map (Figures 8). Hillshade models utilize a false solar shadowing that is processed by the human brain to visualize depth. The slope map more accurately identifies areas of steep slopes by mathematically comparing pixels to determine steepness. The slope map is necessary to help find slopes that may have observable outcrops of geologic units. A color digital elevation model (DEM) was draped over the slope model, and fifty-foot contour lines were added to better illustrate the elevations of the area (Figure 9). This work was completed using a geographic information system (GIS). Maps throughout this report were created using ArcGIS® software version $10.4 \& 10.5$ by Esri. ArcGIS ${ }^{\circ}$ and ArcMap ${ }^{\mathrm{TM}}$ are the intellectual property of Esri and are used herein under license. Copyright (C) Esri. All rights reserved. For more information about Esri® software, please visit www.esri.com.

\section{Field Methods}

Fieldwork was an essential aspect of the mapping effort. Fieldwork consisted of visiting construction excavations, observing road cuts, and mapping gullies. I drove nearly every street in

the annexation area of Kirkland in search of construction sites and road cuts. Also, City Planning and Development Department officials provided listings of sites requiring inspections. These inspection lists provided focused locations for collecting data. The inspection sites normally included some excavation where I was allowed to interpret the subsurface geology (Figure 10). I walked and mapped gullies where streams had cut down through geologic material exposing stratigraphy (Figure 11). I made detailed descriptions of any exposed strata and plotted the site locations using GPS applications on my smartphone. Gully work was extremely time-consuming, taking hours to hack through dense blackberry and brambles with a machete to reach outcrops. 
The updated map contains more than 260 individual field stations, which were added to the map and used to create the 2017 geologic map (Figure 12).

\section{Digital Investigation}

Additional data came in the form of subsurface data from geotechnical investigations, bolstering the map making. Various organizations and private parties supplied borehole data for this project: AESI, Washington State Department of Transportation, City of Kirkland Planning Department, King County and J Keith Cross. This collection of information provided more than 2500 new data points for the creation of the map. The data was organized into a database using GIS. A team of UW undergraduates and former students worked diligently to transcribe the data from hard copy to the GeoMap NW database, digitizing subsurface reports and data logs. This work was done to get geology in developed areas, to aid in the landslide mapping, to obtain groundwater data, and to get material properties.

\section{Map Production}

To make the geologic map, I plotted all field sites and borehole locations initially as points on the slope map (Figure 12). Each location provided some degree of geologic information, generally just soil descriptions. The subsurface data required geologic interpretations. As the interpretations were completed they were plotted on the map as a separate point vector layer of geologic interpretations. Geologic interpretation required diligent study and cross-referencing to assign the materials to stratigraphic units. I used color, density, stratigraphy, gradation and grain size to make the interpretations. Not all subsurface data could be interpreted due to lack of complete descriptions. For example, a subsurface point described simply as "Sand" could not be interpreted as a geologic unit in the absence of other information.

Once the field sites and borehole interpretations were finished, I began producing the geologic map. With the interpretation point layer visible in ArcGIS, a grouping of particular geologic units sometimes became apparent. Using geomorphology, ten and fifty-foot contour lines, elevation, and Steno's laws of geology, I drew polygons in ArcGIS that outlined the extent of each geologic unit. The geomorphological details that I used to interpret the landscape included studying the landforms themselves; the processes that act on those landforms, erosion and mass movement; the method of deposition, glaciations, and the time of the action of these processes. A dearth of data throughout the annexation area meant that geomorphology and Steno's laws played a major role in deciding the extent of the units. The geologic units near the old city limits were connected with the geologic units completed in the 2010 map. Each polygon was identified as its corresponding geological unit in the attribute table, which allowed for proper grouping of units. In addition to geologic units, landforms such as lakes, colluvium, fill, modified land, and landslides were outlined in polygons. The polygons each received a color that matched the colors chosen for the 2010 GeoMap NW project to allow simple integration and identification of units. 
Some of the issues that occurred during map production were the incidental creation of "islands" and overlapping unit polygons. Polygons share borders and hand drawing the shapes often leads to overlaps or spaces (islands) not included in the shape. Topology adjustment tools in ArcGIS can correct these excesses and gaps in shapes and boundaries. Correct topology ensures adjacency and prevents these islands that sometimes form (Bolstad, 2005). The topological relationships are consistent within each individual layer. However, when merging two neighboring shapefiles into a single data set, the software does not automatically create correct topological relationships where the layers adjoin in the output. The "Select Topology" toolset in ArcGIS creates the proper topological relationships, enabling correction of these errors.

\section{Quality Control and Community Inclusion}

This project was a massive endeavor of data and interpretation. This enormity allows errors to creep into the product. I took several steps to make sure that I could achieve the highest client satisfaction. The final steps included having my first reader, Kathy Troost, PhD., review the finished geologic map for accuracy and finally AESI, a Kirkland based geological engineering firm, performed the final review, ensuring a quality product for the city.

Stakeholder involvement was a vital aspect of this project. Monthly meetings with City staff provided progress updates. Interviews with staff members provided additional insight on city geologic features such as springs and seeps and landslides. Also, several neighborhood and city events provided opportunities to inform the public about the mapping project. These engagements also allowed local citizens to take part in the process through interviews and data submission via a City website. 


\section{RESULTS}

This project led to a new 1:12,000-scale geologic map of Kirkland's recently annexed areas (Figure 13). Figure 14 shows an enlarged image illustrating the annexation area.

The mapping project revealed a landscape heavily affected by the most recent glacial advance and retreat. These glacial features include broad recessional channels, broad uplands with drumlins, the Lake Washington Trough, the Sammamish Trough, and steep gullies. Three major channel features dominate the annexation area (Figure 15). The annexation area of Kirkland has been geologically divided into two plateaus by a deeply scoured central outwash channel - channel A in Figure 15. This outwash channel trends nearly north and south. A deeply scoured channel, Juanita Lake Channel, exists within the larger channel and trends NE-SW, (channel C Figure 15). This diagonal channel has eroded from 135 feet elevation in the NE to elevation 20 feet, Lake Washington level, in the SW (Figure 16, C-C'). A branching channel, Totem Lake Channel, trends east-west and connects with the larger north-south trending channel (channel B Figure 15). The channel only drops 30 feet from approximately 140 feet in the east to 114 feet in the west (Figure 16, B-B'). These channels contain recessional outwash and lacustrine deposits. Interestingly, older pre-Vashon glacial units are exposed on the western side of Channel B (see Geologic map Figure 13 and 14), including pre-Vashon glacial till and pre-Vashon fine and course grained-glacial deposits.

The previously mentioned plateaus occupy the remainder of the annexation area. The plateaus are lobate features elongated parallel with the glacial striations, which are indicators for the direction of glacial motion (Galster and Laprade, 1991). The western plateau is higher in elevation than the eastern plateau, but only slightly. The western plateau has a maximum elevation of approximately 480 feet; the eastern plateau is approximately 420 feet maximum elevation (Figure 17, A-A'). These elevations were obtained by comparing plateau elevations obtained from the AA' profile as well as DEM point sampling to find the highest possible elevations. These high points are the drumlins that are labeled on Figure 17.

Deep erosional gullies incise the edges of the plateaus. Rivers and streams seek out baselevel, carving through deposits to achieve this equilibrium. Some of these gullies are post-glacial features, while others developed during recessional lake occupation. These post-glacial erosional gullies erode to Lake Washington. Other gullies developed concurrently with deglaciation. These concurrent gullies end at paleo glacial lake levels (Troost and Wisher, 2010). Many of these concurrent gullies exist on the eastern edge of the Finn Hill plateau. The non-cohesive nature of glacial outwash deposits combined with groundwater seepage makes the material susceptible to erosion. This deep incision is expected given the composition of the plateaus and the high precipitation of the Pacific Northwest.

The surficial geology on the tops of plateaus consists mostly of Vashon glacial deposits. Vashon till units (Qvt) mostly cover the highest elevations on both plateaus. Qvt drapes the area like a blanket, which allows for finding it at all elevations. The western plateau slopes gradually to Lake Washington, and in places, the Vashon till is found at the lakeshore. There are four major 
areas of Qvt, two per plateau. The till appears continuous in these areas, but fensters most likely exist. Vashon till seems to cover approximately 39 percent or 5.0 square miles of the total area of the annexation area (Table 2, Chart 1). A construction excavation along NE $110^{\text {th }}$ st revealed 17 1/2 feet of sandy till. The till formed a vertical wall and probably continued below the excavation as water was pooled on the floor of the excavation. The Vashon till is very dense material visually reminiscent of concrete that is more resistant to erosion than many other deposits. On most of the plateau's slopes, thick deposits of Vashon advance outwash (Qva) are found. The Qva is the next most abundant deposit making up 15 percent or 1.93 square miles of total area (Table 2, Chart 1). This dense to very dense highly compacted unit allows for the steep sides associated with the plateaus. The glacial compaction creates sands that have an angle of repose much higher than the thirty-degree angle of non-compacted sands. I observed 36 feet of Qva at an excavation in Finn Hill, at the end of $80^{\text {th }}$ Ave NE. The advance outwash was extremely clean sand, well-sorted and poorly-graded under five feet of till, which contained sandy silt lenses. In very few locations across the annexation area, 2 percent or 0.22 square miles, the Lawton Clay unit (Qvlc) is exposed beneath the Qva (Table 2, Chart 1). The unit is often associated with an erosional gully, a steep bluff or, landslide features.

The surficial geology of the recessional channels consists mostly of Vashon recessional material. The Vashon recessional outwash (Qvr) fills low-lying areas and shorelines in addition to the large channels described previously. Recessional outwash occupies approximately 8 percent or 1.07 square miles of annexation areas, mostly in the northern annexation area (Table 2, Chart 1). Associated with the Qvr is the recessional lacustrine deposits that formed with the lakes such as historical Lake Bretz (120-150 feet), discussed in the background section. Recessional Lake Juanita (50-90 feet) and Lake Totem (160-180 feet) were identified as well. These soft and loose deposits may contain more organic material than the recessional outwash, which allows them to be radiocarbon dated. These recessional lake deposits are not compact and are interbedded silt and silty fine sand. Elevation of the deposits is the main method for identifying the separate lakes. Recessional Lake deposits make up 28 percent of the total annexation area. Soft peat deposits in the area suggest prior wetlands in areas where lake levels change. Table 2 and Chart 1 illustrate all of the geologic units and their percent area of coverage compared with the Minard 1983 map. A description of mappable units can be found in Table 3.

On a gradually sloping southern flank of the Finn Hill plateau, there is a large section of coarse-grained non-glacial deposits. The deposits consist of very dense sand and gravels.

Many landslide features were discovered in the annexation area. The landslides are relatively easy to identify with high-resolution LIDAR. I positively identified at least forty landslides (Figure 18). The western plateau has the most identifiable landslides, around thirty landslides. The largest landslide headscarp is at least 1250 feet long. This landslide is located on the northern section of the western plateau. A large landslide occurred in a Finn Hill neighborhood during this project (Figure 19 and 20). The slide uprooted and displaced mature trees and ran up the opposite valley wall approximately 50 feet (Figure 21). I was able to observe theVashon glacial stratigraphy exposed by the slide. Figure 22 illustrates this landslide's location in 
Finn Hill. Many more landslides may be identified in the LiDAR with further focused landslide investigation. 


\section{DISCUSSION}

Exposures within the city are limited to outcrops in erosional gullies, landslide scarps, roadcuts and construction excavations. These exposures were well-utilized to create my geologic interpretations. Much of the annexed area consists of well-established neighborhoods with no new construction or bore hole data leading to a dearth of data in these areas.

Kirkland's annexation area is divided into broad plateau uplands divided by multiple large channels. These channels were likely formed by subglacial outwash or outburst floods from the receding glacier similar to those discussed by Minard and Booth (1988) in Redmond and Borden and Troost (2001) in Pierce County. Subglacial meltwater has extremely high pressures that are derived from the weight of the ice above it, in this case, the Vashon lobe, over one mile of ice (Porter and Swanson, 1998). Because of the high pressures, the meltwater has immense ability to scour deep into the material beneath the glacier. For example, the more than 600 feet deep Puget Sound and 400 feet Lake Washington are both the result of subglacial scour (Lyster et al., 1967, Booth and Hallet, 1993, Booth et al., 2003). The carving out of the channels has exposed PreVashon units. Massive very stiff to hard, laminated, grey, fine-grained clay units lie above the older glacial units. These units represent transitions from non-glacial to early glacial periods. The finegrained units accumulated as intruding ice lobes created large proglacial lakes by damming outlets. The clay units above the Pre-Vashon units help determine their relative ages.

I compared my map to that of Minard (1983) (Figure 23), the only geologic map available for the annexation area. His map displays ten units, which include landslides and modified land. He has four Vashon glacial units and a transitional unit. The last three units displayed are two alluvium units, Holocene and older, and, lastly, a pre-Frasier till unit. Table 2 and Chart 1 illustrate the breakdown of Minard's units with the percent area coverage included compared with the 2017 Kirkland Annexation map. I was able to identify twenty-seven units in my study of the Kirkland annexation area. Of course, we have some identical units, Qvt, Qva, Qls, m. The differences lie in the details. I separated the recessional lacustrine units from recessional outwash units, whereas these were lumped together by Minard. I further increased resolution by separating the lacustrine units into individual lake levels. Our differing treatment of the transitional beds adds additional detail. Minard lumps glacially overridden peat and thick laminated clays, glacial and non-glacial deposits. I have separated peat, wetlands and Lawton clay into individual units. I also include mass wasting and colluvium units on the map as it, along with vegetation, makes up much of the slope cover found in the area.

Interestingly, Minard's map is in agreement with my map, having Qvt blanketing only the highest areas of the two plateaus (except the western plateau having till coverage to Lake Washington level). His finding correlates with mine that probably a large outburst flood or subglacial hydrologic pressure jets removed the Qva and Qvt in these areas leaving the two high elevation plateaus separated by a channel. The channel is filled with recessional outwash and recessional lacustrine units. The scouring also exposed Pre-Vashon fine-grained glacial deposits.

Major improvements to the 1983 map are changes in the percent area coverage of units (Table 2 Chart 1). My on-the-ground research along with the borehole data show 26 percent less 
coverage of Qvt than previously mapped. The Minard map has Qvt covering 65 percent of the total annexation area. Not only did I visually establish the presence of windows in the vast swaths of till, I found two percent more advance outwash than the previous map shows. The increase in outwash equates to more water infiltration in these area. The till is semi-permeable allowing infiltration mostly through the many discontinuities throughout the unit.

A blatant difference between the two maps, and one that shows the value of modern LIDAR technology is the absence of large landslides on Minard's map that were obvious on my percent slope maps (Figure 18). These landslide features appear very clearly on the new maps. The high-resolution LIDAR allows a landslide's arcuate scarps and hummocky terrain to stand out. In fact, with Minard's map overlain on the slope map (Figure 23), the landslides mapped in 1983 are not obvious. The absence of former hummocks and scarps may be because of diffusion or modern grading, but LIDAR has proven itself valuable in identifying historic landslides. 


\section{CONCLUSION}

A map of the surficial geology of the northern annexation area of the City of Kirkland is presented in this report. The impetus for the project is the tragic events of March 2014 at the North Fork Stillaguamish River and the proactive actions of Kirkland City Council and Managers to provide for the safety, well-being, and growth of the City. Annexation of unincorporated areas in 2011 left the city with an area equal its size having antiquated low-resolution geologic maps from 1983. This project's data collection consisted of a combination of fieldwork and compilation of subsurface exploration reports. Construction site visits and roadcut and gully exploration made up the bulk of fieldwork. The reports were mined from many different sources; county and city repositories, engineering firms and private persons. All data was entered into the GeoMap NW database, which will be shared with the Washington Geological Survey for inclusion on their website. Subsurface reports had to be interpreted to determine the geologic units described within. All data manipulation was handled with ESRI GIS products, specifically ArcGIS 10.4.1. Several derivative maps were created with the interpretation of the geology, including percent slope map, landslide map, and a map of geologic units based on infiltration potential and grain size.

The city geology was found to be heavily shaped by the incursion and retreat of Pleistocene glaciers. Outburst floods and subglacial hydraulic scouring created major channels that dominate the center of the annexation area. Recessional outwash, recessional lacustrine deposits and Holocene alluvium units are found in the channels. Two high elevation plateaus, which occupy the rest of Kirkland's annexed area. Pre-Vashon fine and coarse-grained material crops out in erosional gullies. Differentiating between these pre-Vashon and Vashon glacial units is nearly impossible without age control. In most cases, these units have identical characteristics. The best way to identify between these is to find the younger material stratigraphically above, the older material.

Kirkland slopes consist of Qva covered in slope wash, Lawton Clay (Qvlc), Olympia Beds or in some cases pre-Frasier glacial deposits. Vashon till blankets the plateaus. The till is not continuous across the plateaus. Qvlc is often exposed in the steep erosional gullies or landslide scarps. The pre-Frasier deposits and the Olympia Bed deposits are evidence of paleotopography that was exposed by scour. The scale of this investigation revealed 26 percent less till in the annexation area than previously mapped. This change in material from previously mapped affects infiltration values for the changed areas. 


\section{LIMITATIONS}

Limitations to geologic mapping exist in urban areas. These limitations include difficulties associated with densely developed well-established neighborhoods and limited subsurface exploration reports. Well-established neighborhoods see very little new construction and that new construction provided the bulk of the field sites throughout the city. This dearth of construction led to data gaps throughout the mapping area. Data gaps force the interpolation of geology in areas lacking data which introduces errors into the final map on the side of more till. Years of urban development led to an abundance of modified land in the annexation area. In some cases, in situ geology was only discovered under several feet of fill. An interpretation of geology in an area where the land is heavily modified may be suspect. Also, in the urban setting, outcrops are virtually nonexistent; roadcuts were taken advantage of to expose some of the geology. Exposures were often only discovered after hours of bushwhacking down erosional gullies. Sometimes even this effort proved fruitless. Additionally, borehole reports did not always contain enough description to make a good interpretation of material. At a minimum, density and material type are required to interpret the geologic unit present. Even with high-quality reports, interpreting stratigraphy is difficult because radiocarbon dating is rarely available.

Limitations to mapping geology exist when thick colluvium or thick forest and vegetation cover exist in the area. The steepness of slopes and non-compact geology lead to thick colluvial cover on most of the slopes in the annexation area. Geology is hidden beneath this thick layer of colluvium. As mentioned previously, thick vegetation cover and dense forest make many of the area gullies impassable without a machete. Also, gully exploration is extremely time consuming.

The map scale and scope of the area is a limitation given the amount of time allotted to complete the work. Field work began in the summer of 2016 and continued until April 2017. Continued field work would have reduced the effect of data gaps and other limitations mentioned previously. Working on the map at a 1:1000 scale was a very time intensive endeavor.

This map is an interpretation of the evidence that $\underline{I}$ found in the area. The map is therefore limited bv that interpretation. 


\section{REFERENCES CITED}

Armstrong, J., Crandell, D., Easterbrook, D., and Noble, J., 1965. Late Pleistocene Stratigraphy and Chronology in Southwestern British Columbia and Northwestern Washington. Geological Society of America Bulletin, 76(3), 321-7606-76-3-321-23012.

Atwater, B. F., 1987. Evidence for great Holocene earthquakes along the outer coast of Washington State. Science, 236, 942.

Bolstad, P., 2005. GIS Fundamentals: A First Text on Geographic Information Systems. Eider Press.

Booth, D.B. and Hallet, B., 1993. Channel networks carved by subglacial water - observations and reconstruction in the eastern Puget Lowland of Washington. Geological Society of America Bulletin, 105, 671-683.

Booth, D. B., Troost, K. G., Clague, J. J., and Waitt, R. B., 2003. The Cordilleran ice sheet. Developments in Quaternary Sciences, 1, 17-43.

Booth, D., Troost, Kathy G, Shimel, and Scott A, 2005. Geologic map of northwestern Seattle (part of the Seattle North 7.5 X 15 quadrangle), King County, Washington (Scientific investigations map; 2903). Reston, Va.?]: U.S. Geological Survey.

Borden, R. and Troost, Kathy G., 2001. Late Pleistocene stratigraphy in the south-central Puget Lowland, Pierce County, Washington, Report of investigations. Olympia, WA: Washington State Dept. of Natural Resources.

Chleborad, A. F., Baum, R. L., and Godt, J. W., 2006. Rainfall thresholds for forecasting landslides in the Seattle, Washington, area-exceedance and probability (No. 2006-1064).

City of Kirkland, 2016, accessed 7/15/2017, from City of Kirkland website: http://www.kirklandwa.gov/.

Easterbrook, D., 1962. Pleistocene geology of the northern part of the Puget Lowland, Washington. University of Washington.

Esri, ArcGIS Resources: Release 10.4 and 10.5. Redlands, CA, Environmental Systems Research Institute, http://resources.arcgis.com/en/help/ (accessed July 2016).

Galster, R. W., and Laprade, W. T., 1991. Geology of Seattle, Washington, United States of America. Bull Assoc Eng Geol, 28(3), 235-302.

Haugerud, R.A., 2009. Preliminary geomorphic map of the Kitsap Peninsula, Washington: U.S. Geological Survey, Open-File Report 2009-1033, 2 sheets, scale 1:36,000, available at http://pubs.usgs.gov/of/2009/1033/.

Johnson, S., Potter, C., and Armentrout, J., 1994. Origin and evolution of the Seattle fault and Seattle basin, Washington. Geology, 22(1), 71. 
Johnson, Potter, Armentrout, and Miller., 1996. The southern Whidbey Island fault: An active structure in the Puget Lowland, Washington. Geological Society of America. Geological Society of America Bulletin, 108(3), 334.

Johnson, S., Dadisman, S., Childs, J., and Stanley, W., 1999. Active tectonics of the Seattle fault and central Puget Sound, Washington--Implications for earthquake hazards. Geological Society of America. Geological Society of America Bulletin, 111(7), 1042-1053.

Koster, K., Erkens, G., and Zwanenburg, C., 2016. A new soil mechanics approach to quantify and predict land subsidence by peat compression. Geophysical Research Letters, 43(20), 10,792-10,799.

Lisle, R. J., Brabham, P., and Barnes, J., 2013. Basic Geologic Mapping. Environmental \& Engineering Geoscience, 19(2), 196-198.

Lister, C.R.B., Whetten, J.T., and McKee, B. 1967. Sonar reflection profiling on the Columbia River and in Lake Washington. Northwest Science, Vol. 41, No. 4, pp. 152-154.

Mace, C. G., and Keranen, K. M., 2012. Oblique fault systems crossing the Seattle Basin: Geophysical evidence for additional shallow fault systems in the central Puget Lowland. Journal of Geophysical Research: Solid Earth, 117(B3).

McCormack, D.H., and Troost, K., 2016. Quaternary Geology of Northwestern King County and Southwestern Snohomish County, Washington, in The geology of Washington and beyond: From Laurentia to Cascadia. Seattle: Washington Division of Geology and Earth Resources. Edited by Cheney, E.S., University of Washington Press.

Minard, J.P., 1983. Geologic Map of the Kirkland Quadrangle, Washington. 1:24000. Miscellaneous Field Studies, map MF-1543. Denver, CO: U.S. Geological Survey.

Minard, J. P., and Booth, D. B., 1988. Geologic Map of the Redmond Quadrangle, King County, Washington (No. 2016).

Mullineaux, D. R., Waldron, H. H., and Rubin, M., 1965. Stratigraphy and chronology of late interglacial and early Vashon glacial time in the Seattle area, Washington (No. 1194-O). USGPO,.

Porter, S. C., and Swanson, T. W., 1998. Radiocarbon age constraints on rates of advance and retreat of the Puget lobe of the Cordilleran ice sheet during the last glaciation. Quaternary Research, 50(3), 205-213.

Sherrod, B., Blakely, R., Weaver, C., Kelsey, H., Barnett, E., Liberty, L., Meagher, K., and Pape, K., 2008. Finding concealed active faults: Extending the southern Whidbey Island fault across the Puget Lowland, Washington. Journal of Geophysical Research: Solid Earth, $113(\mathrm{~B} 5), \mathrm{N} / \mathrm{A}$.

Troost, K., and Booth, D., 2008. Geology of Seattle and the Seattle area, Washington. Reviews in Engineering Geology, 20(0), 1-36. 
Troost, K., and Wisher, A.P., 2010. Geologic map of Kirkland, Washington. 1:12000.

Tubbs, D. W., 1974. Landslides in Seattle. Department of Natural Resources.

U.S. Geological Survey, 2006, Quaternary fault and fold database for the United States, accessed 5/15/2017, from USGS web site: http//earthquakes.usgs.gov/hazards/qfaults/.

Wartman, J., Montgomery, D.R., Anderson, S.A., Keaton, J.B., Benoît, J., Dela Chapelle, J., and Gilbert, R., 2016. The 22 March 2014 Oso landslide, Washington,

USA. Geomorphology, 253, 275-288.

Washington Division of Geology and Earth Resources, 2013, Washington interactive geologic map, accessed 5/15/2017, from Washington DNR web site: http://www.dnr.wa.gov/geologyportal. 


\section{FIGURES}

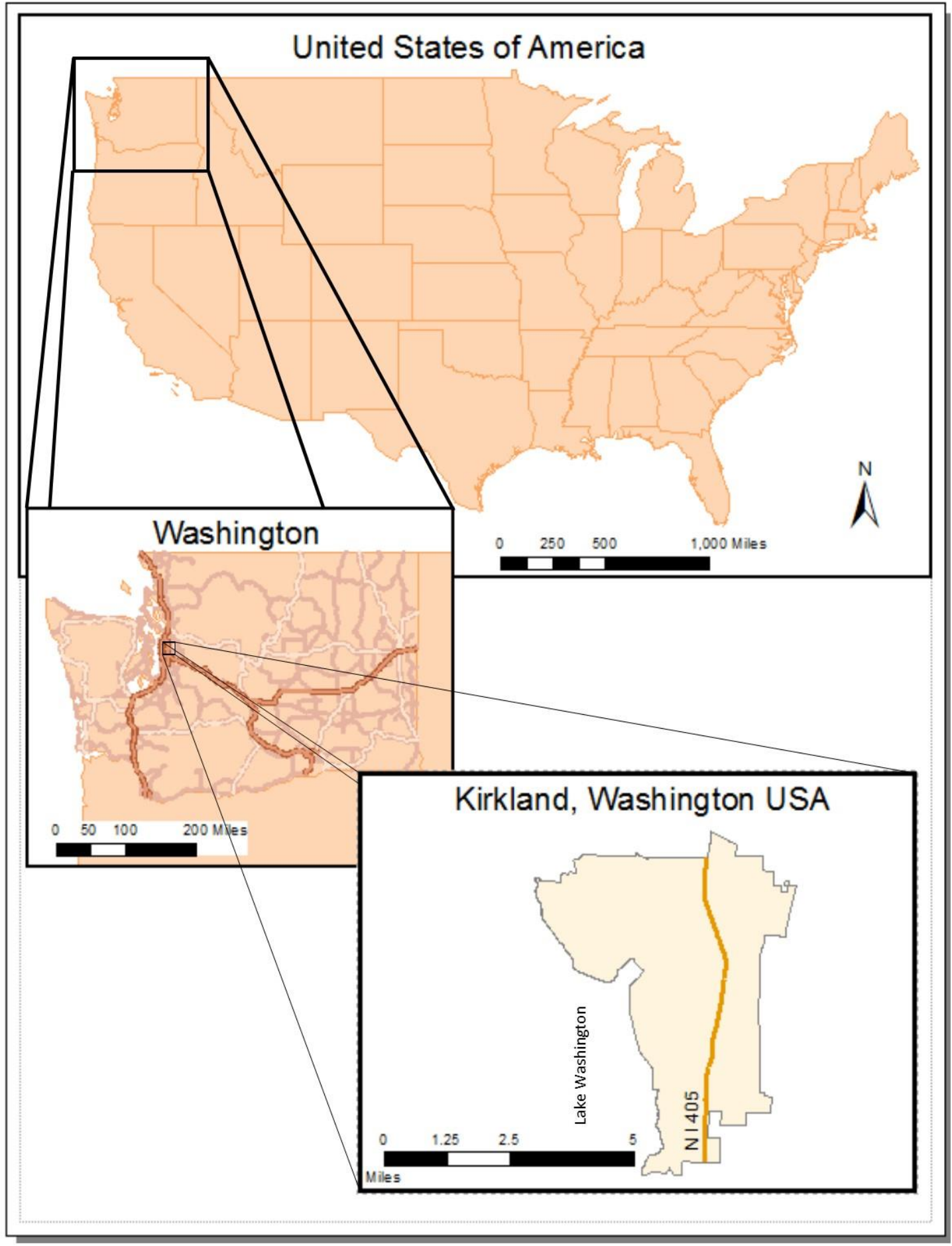

Figure 1: Vicinity map of Kirkland, Washington, which lies to the east of Seattle and Lake Washington, to the north of SR 520, to the south of Bothell and Kenmore and to the west of Redmond and Woodinville. 


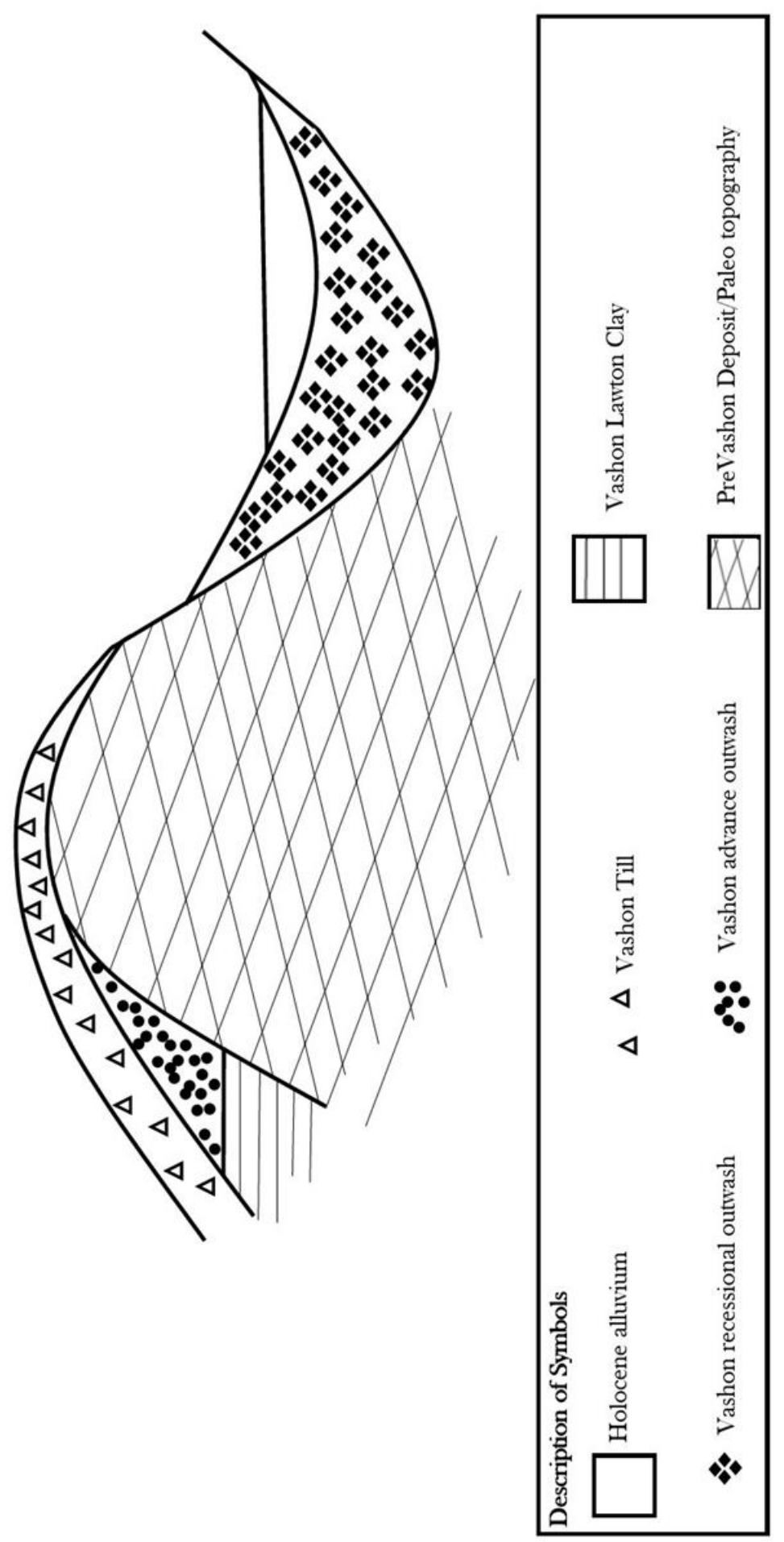

Figure 2: Illustrates the stratigraphic relationships of the deposits found in the Kirkland area. 


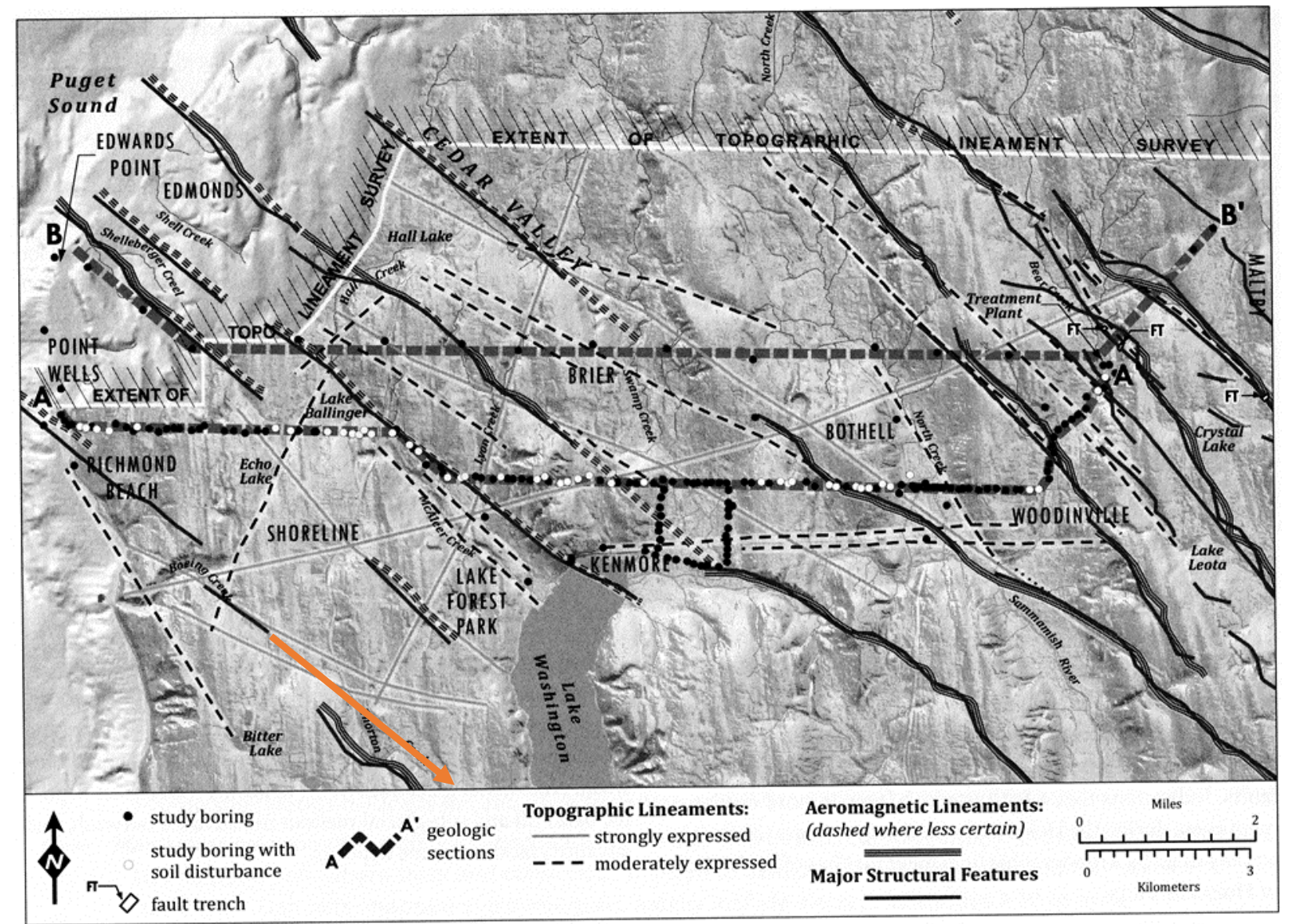

Shaded relief topography of the study area (from lidar surveys except for the northwest corner where 30-m digital elevation model data were used). We identified topographic lineaments from lidar images. Magnetic lineament locations are from Blakely et al. (2004); we have interpreted them on the basis of strength and continuity of magnetic gradients. We show steepest gradients over the edges of the causative feature, some of which Sherrod et al. (2008) believe are faults. Evidence for a fault origin for a lineament is strongest where topographic and magnetic lineaments generally coincide. Borehole data indicate that stratigraphic displacements and post-depositional sediment disturbances are more prevalent within a kilometer of magnetic lineaments than beyond; zones affected by magnetic lineaments may be as much as $2 \mathrm{~km}$ wide.

Figure 3: Topographical lineaments outlined by McCormack and Troost, 2015 might indicate fault trends. Kirkland lies beyond the study range so the author extends a lineament towards the Kirkland city limits as an example of the possibility of faults affecting the City and the importance of the Geologic map. The orange arrow extrapolates the lineament towards Kirkland city limits. The image without the orange arrow is from McCormack and Troost, 2015. 


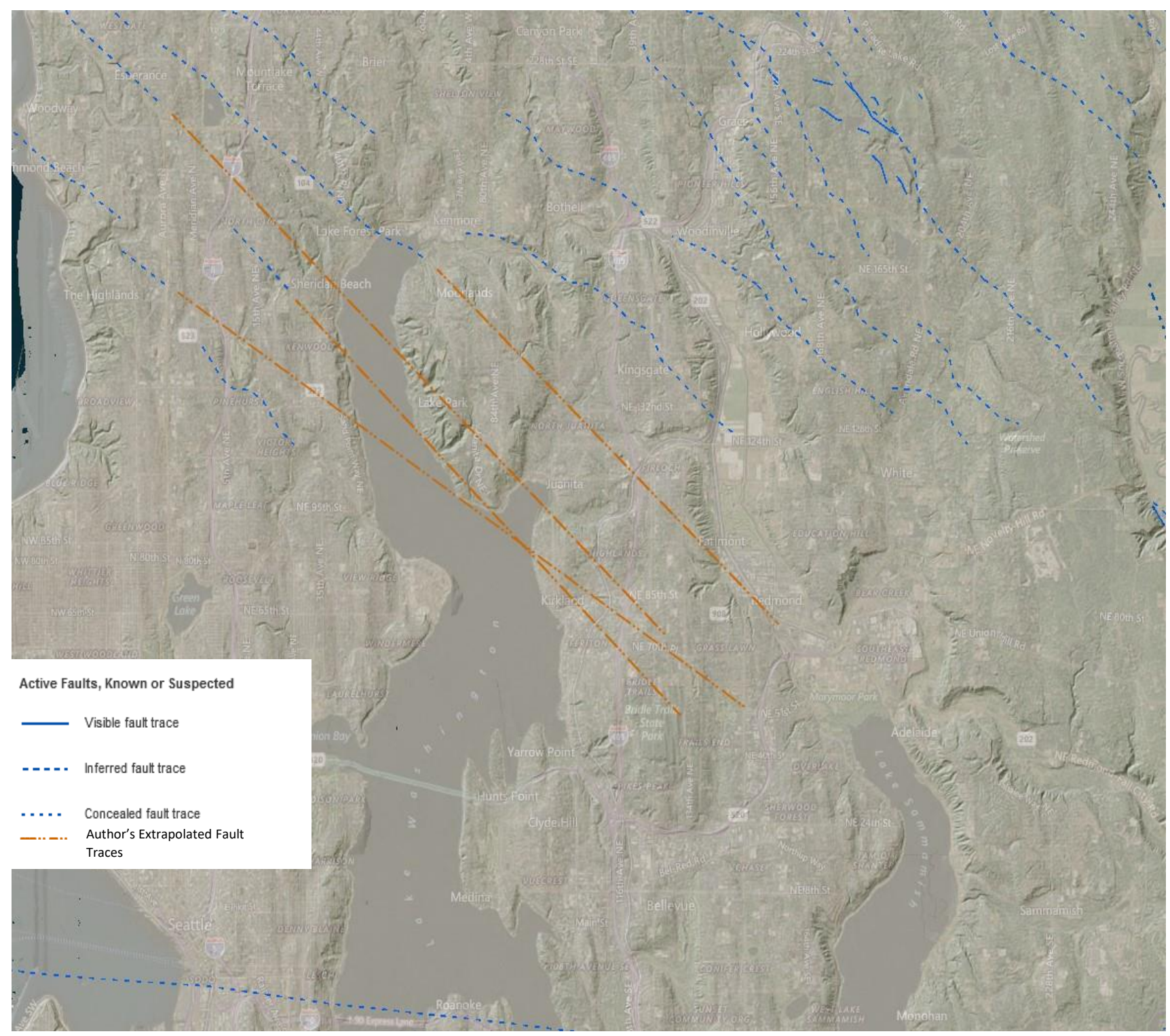

Figure 4: I extrapolated fault traces from Washington Geological Survey inferred fault traces and the topographical lineaments from McCormack and Troost, 2015, figure 2. The extrapolated lines in no way indicate the presence of faults in those areas, only a possibility of faults if the fault traces extend past their inferrence. These extrapolations only illustrate the importance of the geologic map and the possibility of seismic hazard for the City. 


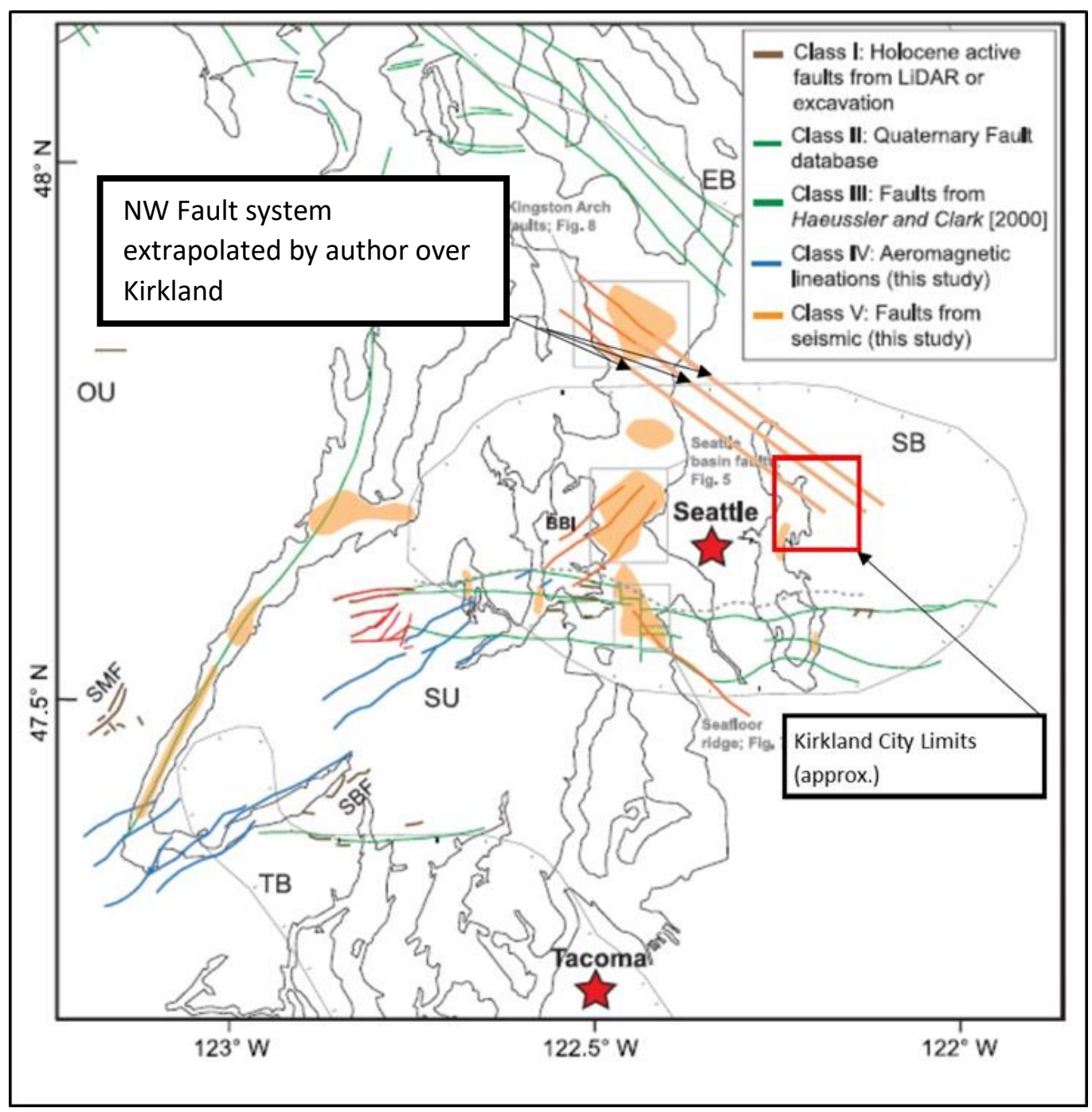

Faults identified from seismic reflection and aeromagnetic data in this study, plotted with regional basins and the existing Quaternary Fault Database (http//earthquakes.usgs.gov/regional/qfaults) and with faults mapped from geologic mapping [Haeussler and Clark, 2000], identified from lidar data, and/or excavated [Nelson et al., 2003, 2008; Witter et al., 2008]. The northern boundary of the SFZ is drawn in the thin, east-west trending dashed gray line [Kelsey et al., 2008]. Shaded areas show regions of deformed shallow sediment mapped in this study. The mapped $\mathrm{N} 60^{\circ} \mathrm{E}$ fault system from seismic is collinear with the fault system mapped from aeromagnetic data. The Sunset Beach Fault scarp (SBF) is shown within the southern Seattle Uplift and trends subparallel to the $\mathrm{N} 60^{\circ} \mathrm{E}$ fault zone on its southern margin. Mapped surface faults are also subparallel to the fault zone. Other abbreviations are SB, Seattle Basin; EB, Everett Basin; TB, Tacoma Basin; SU, Seattle Uplift; OU, Olympic Uplift; BBI, Bainbridge Island; SMF, Saddle Mountain Fault.

Figure 5: Mace and Keranen (2012) illustrate recently discovered lineations and faults (Class IV and Class $V$ respectively) trending $\mathbf{N E}$ and $N W$. II extrapolated Mace and Keranen's $N W$ trending Class V faults to the Kirkland City limits (red box). These extrapolations in no way indicate the presence of faults in that location. The extrapolations only illustrate the importance of the geologic map should faults be discovered within the City. 


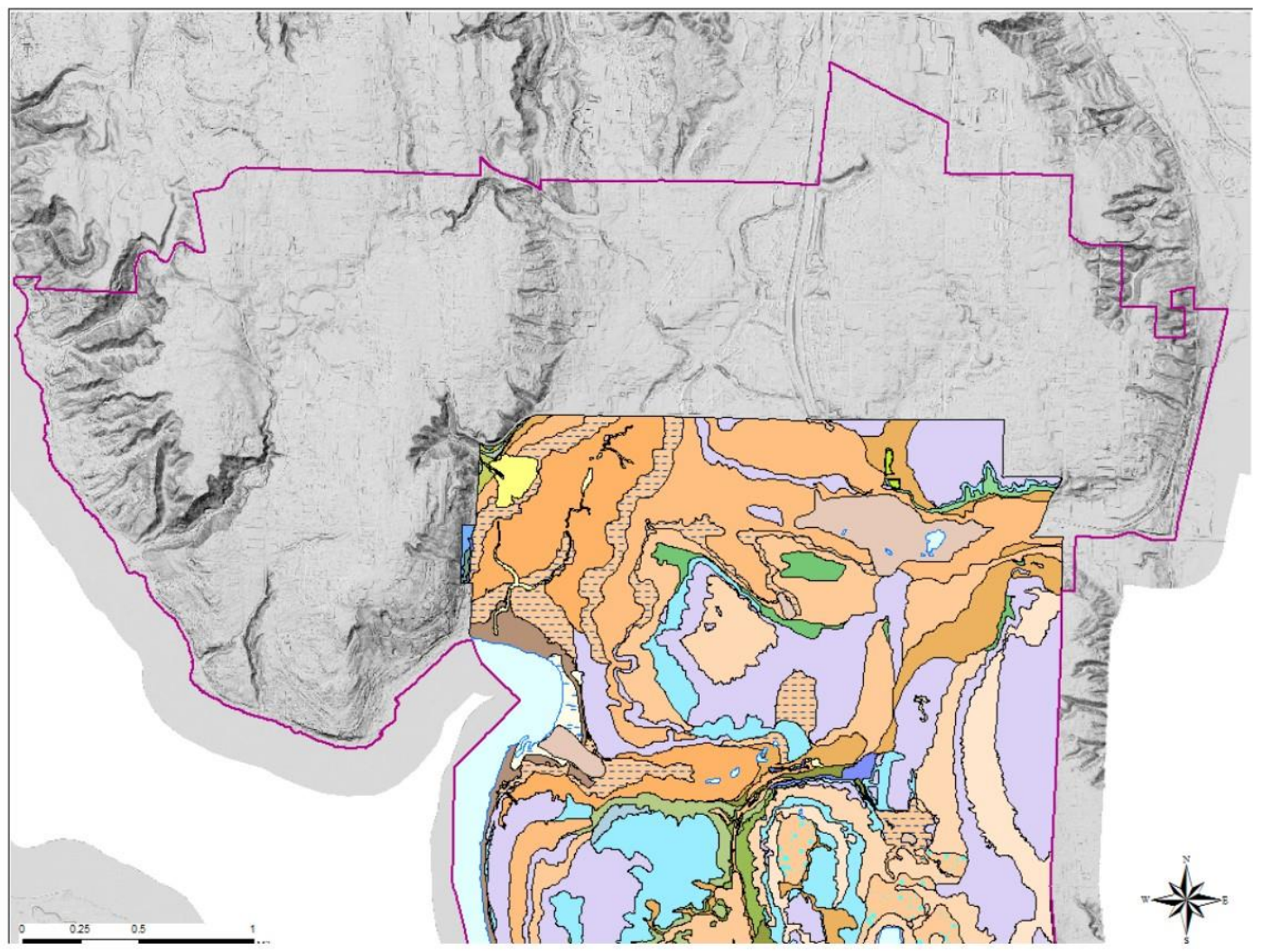

\begin{tabular}{|c|c|c|c|}
\hline \multicolumn{4}{|c|}{ Geologic Units } \\
\hline Units & & & Qvt - Vashon subglacial till \\
\hline \multicolumn{2}{|c|}{ Non Glacial Deposits (Holocene) } & & Qva - Vashon advance outwash deposits \\
\hline & water & & 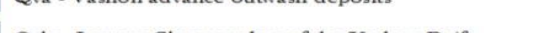 \\
\hline \multirow{3}{*}{$=3$} & \multirow{2}{*}{ Qw - Wetland deposits } & & Qvlc - Lawton Clay member of the Vashon Drift \\
\hline & & \multicolumn{2}{|c|}{ Older Glacial and Nonglacial Deposits (Pleistocene) } \\
\hline & Qp - Peat and organic-rich deposits & & Qpf - Pre-Fraser glaciation age deposits \\
\hline & Qal - Alluvium & & Qpff-Pre-Fraser fine-grained deposits \\
\hline & Q1 - Lake deposits & & Qpfn-Pre-Fraser nonglacial deposits \\
\hline & Qf - Fan deposits & & \multirow{3}{*}{$\begin{array}{l}\text { Qpfnc-Pre-Fraser coarse-grained nonglacial deposits } \\
\text { Qpfnf-Pre-Fraser fine-grained nonglacial deposits }\end{array}$} \\
\hline \multicolumn{2}{|c|}{ Younger Glacial Deposits (Fraser Glaciation, Pleistocene) } & & \\
\hline & Qvr - Vashon recessional outwash deposits & & \\
\hline & \multirow{2}{*}{ Qvr1 - Vashon recessional lacustrine deposits } & & Qob-Olympia beds \\
\hline 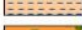 & \multirow{2}{*}{\multicolumn{2}{|c|}{ Qvilo - Vashon recessional lacustrine deposits (organic) }} & \multirow{3}{*}{ Qpoc-Pre-Olympia coarse-grained deposits } \\
\hline- & & & \\
\hline & \multicolumn{2}{|l|}{ Qvrlj - Vashon recessional Lake Juanita deposits $\left(50^{\prime}-90\right)$} & \\
\hline & \multicolumn{2}{|l|}{ Qurlb - Vashon recessional Lake Bretz deposits (120'-150') } & Qpog - Pre-Olympia glacial deposits \\
\hline & \multirow{2}{*}{ Qvrlt - Vashon recessional Lake Totem deposits $\left(160^{\prime}-180^{\prime}\right)$} & & \multirow{2}{*}{$\begin{array}{l}\text { Qpoge-Pre-Olympia coarse-grained glacial deposits } \\
\text { Qpogf-Pre-Olympia fine-grained glacial deposits }\end{array}$} \\
\hline & & & \\
\hline & Qvrlf - Vashon recessional Lake Forbes deposits (240'-280) & & \multirow{3}{*}{$\begin{array}{l}\text { Qpogt-Pre-Olympia glacial till } \\
\text { Qpon-Pre-Olympia nonglacial deposits }\end{array}$} \\
\hline & \multirow{2}{*}{ Qvrlr - Vashon recessional Lake Russell deposits (300-330') } & & \\
\hline & & & \\
\hline & Qvrlbt - Vashon recessional Lake Bridal Trails deposits (490'-520) & & \multirow{2}{*}{ Qpone-Pre-Olympia coarse-grained nonglacial deposits } \\
\hline & Qvi - Vashon ice-contact deposits & & \\
\hline
\end{tabular}

Figure 6: Troost and Wisher, 2010 geologic map of Kirkland did not include annexation area. 


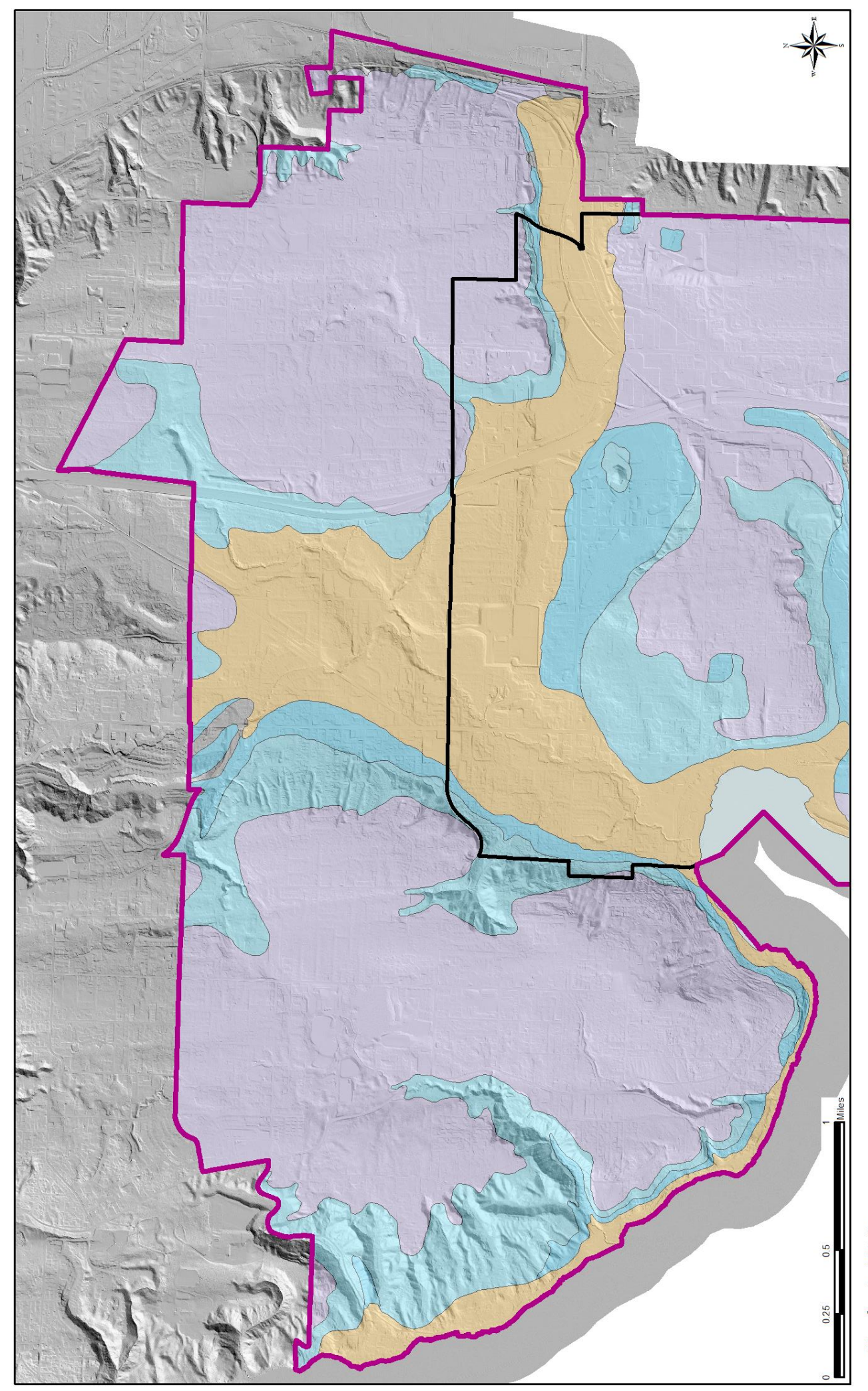

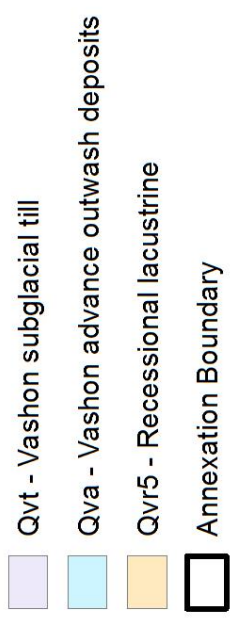

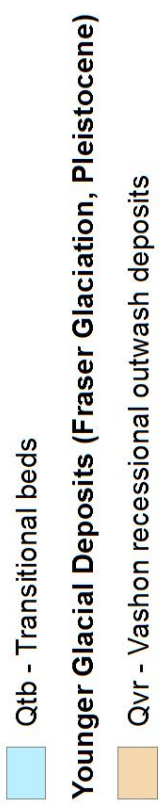

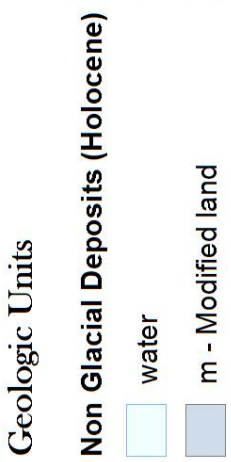

Figure 7: Minard 1983 geologic map of annexation area. 


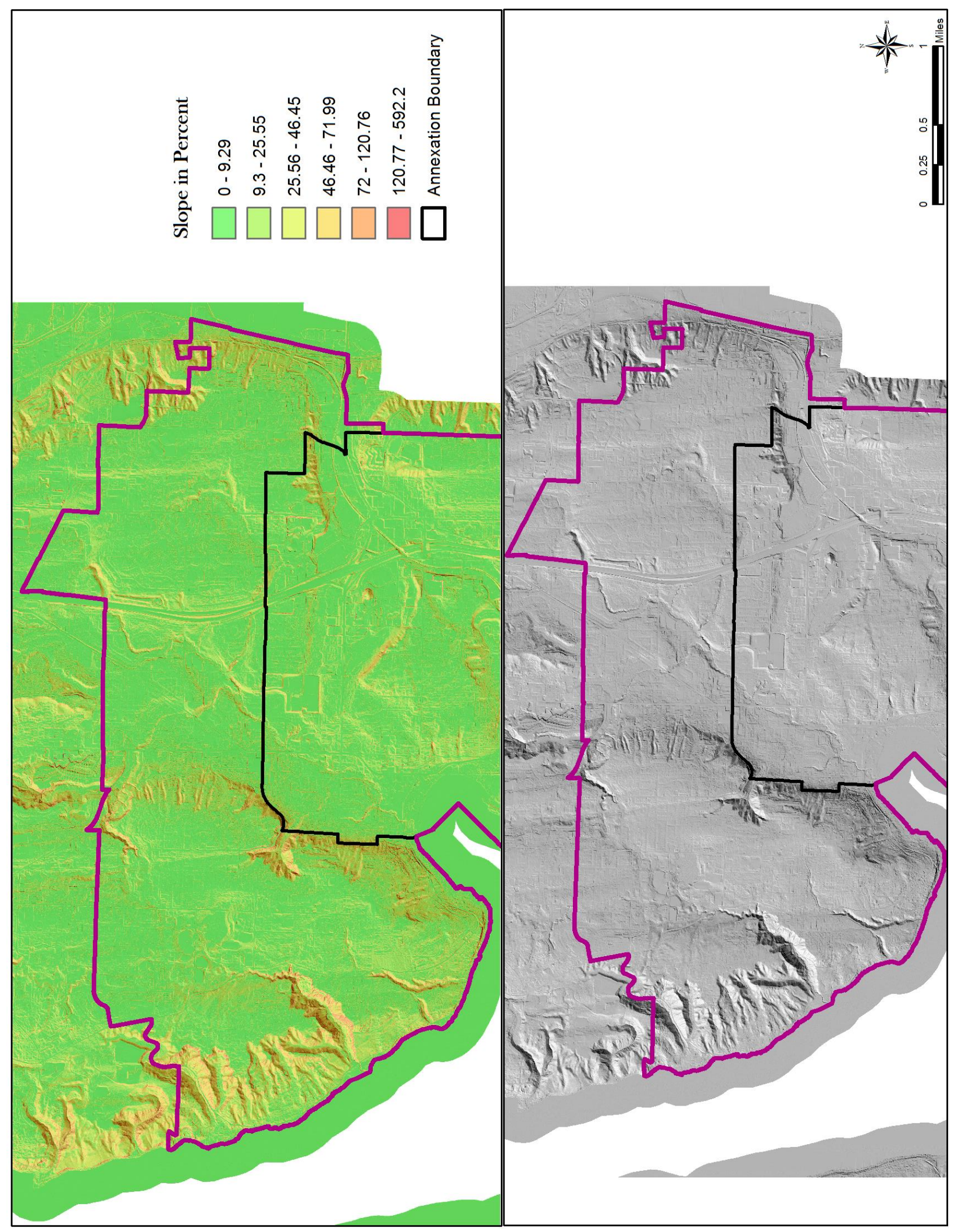

Figure 8: A percent slope map (top) and a hillshade model (bottom) of the Kirkland annexation area. These were created from the 2016 LIDAR scans of the City. 


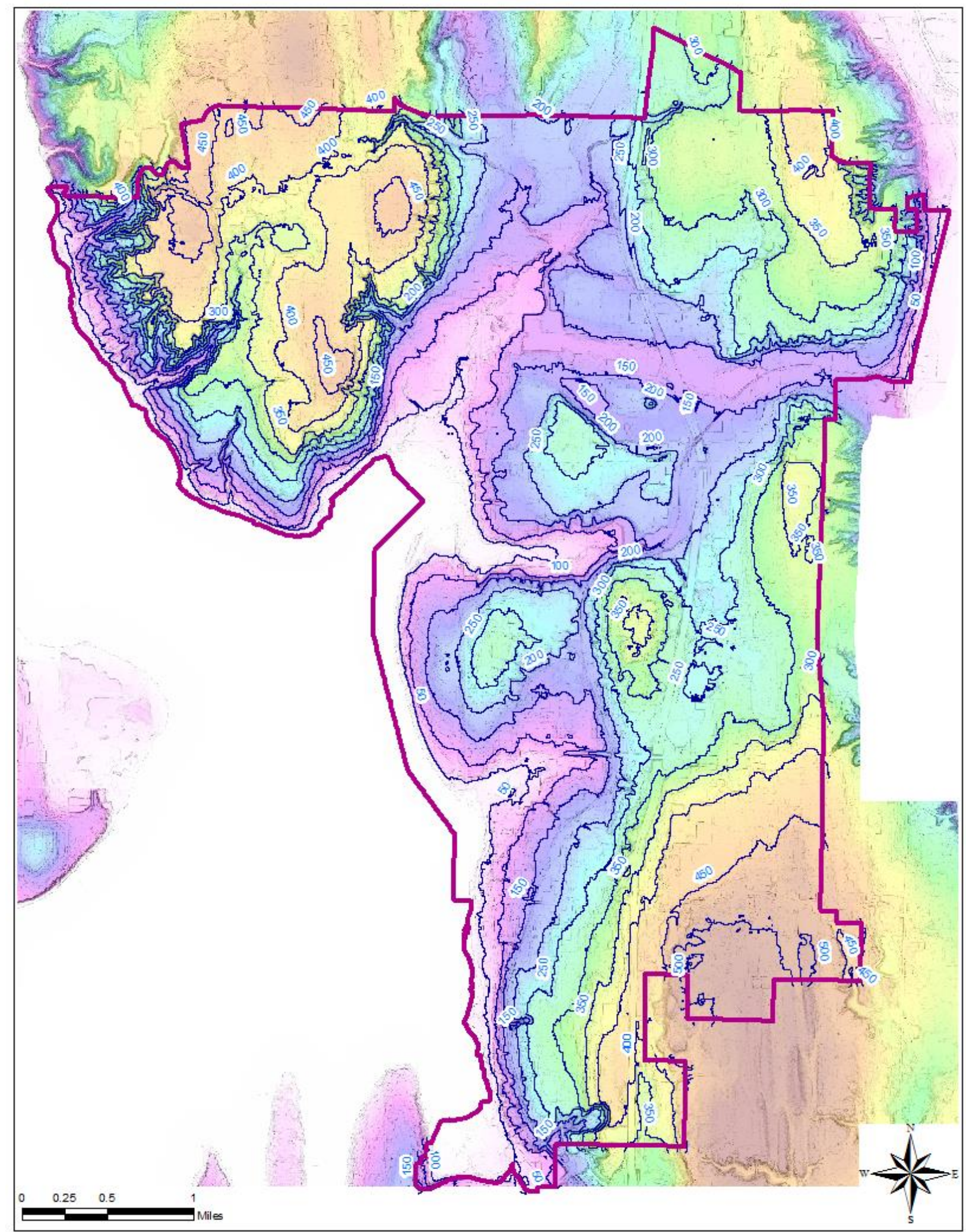

Figure 9: A digital elevation model (DEM) of Kirkland created from the most recent LIDAR data draped over a slope map. Contour interval (blue line) is 50 feet. 


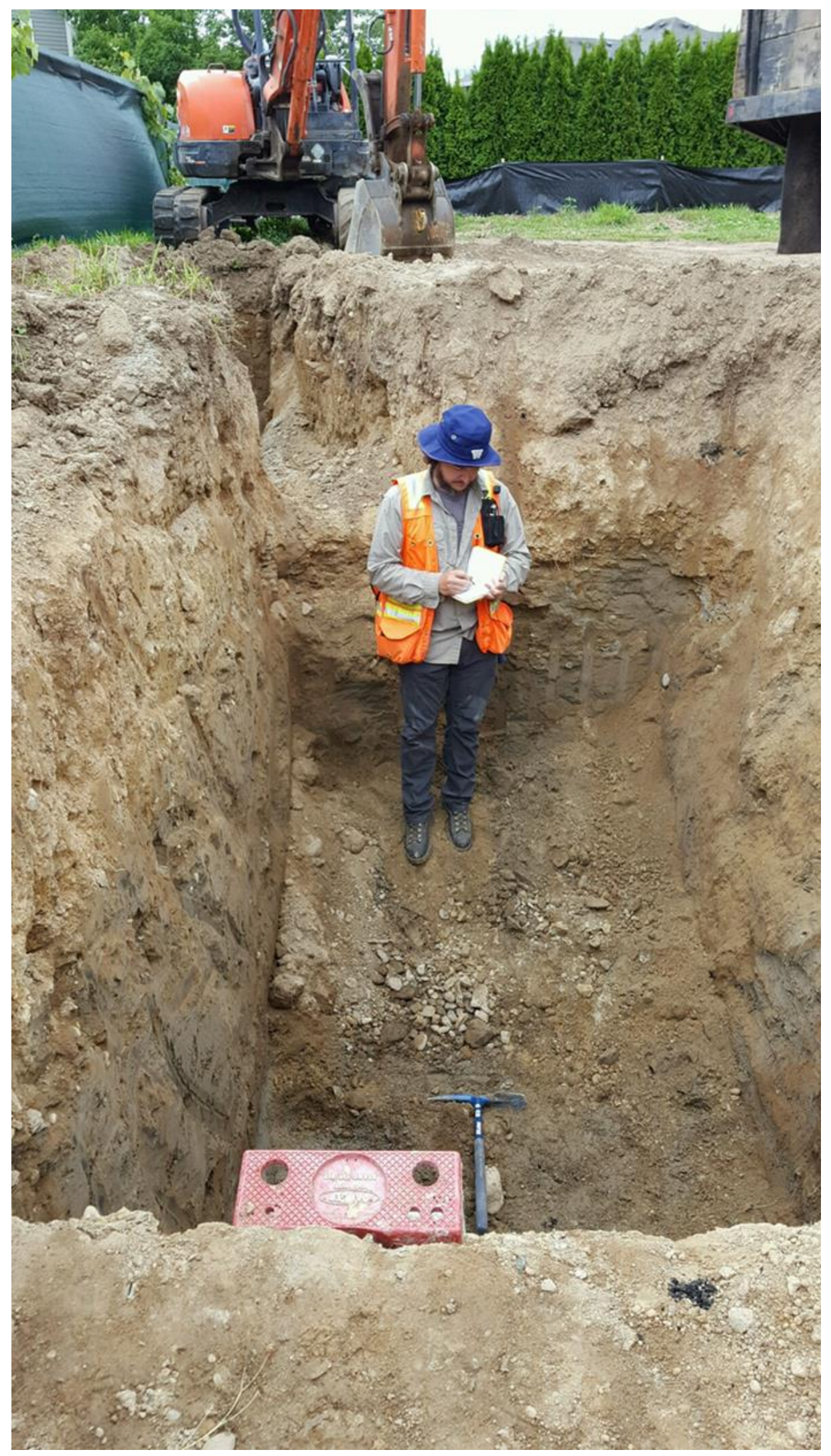

Figure 10: The author making observations at a construction excavation in Vashon Till (Qvt). 


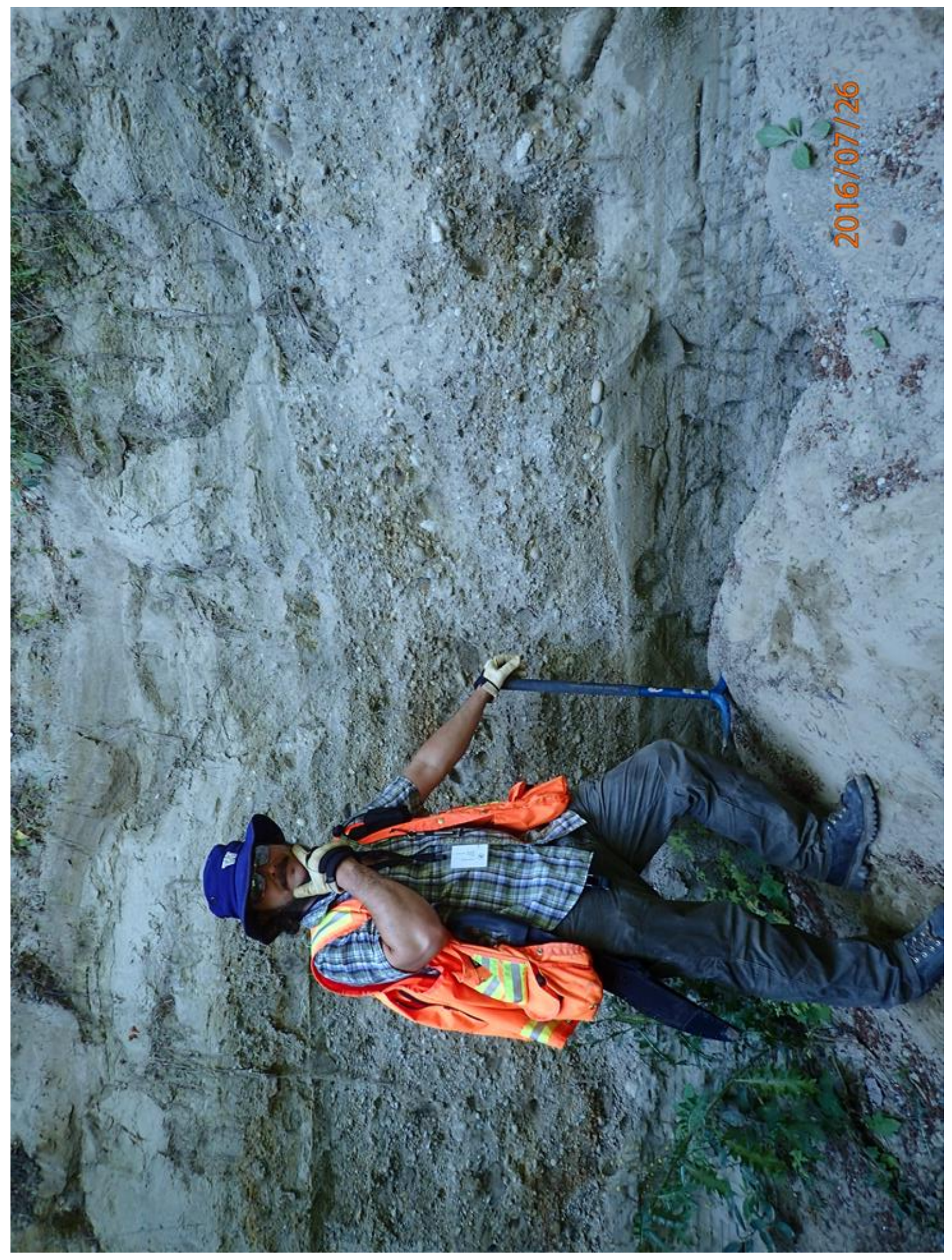

Figure 11: The author contemplating an outcrop of Vashon advance outwash (Qva) discovered in an area gully; the result of hours of machete work through blackberry bushes in a steep ravine. Note the interbedded nature of silt, sand and gravel. 


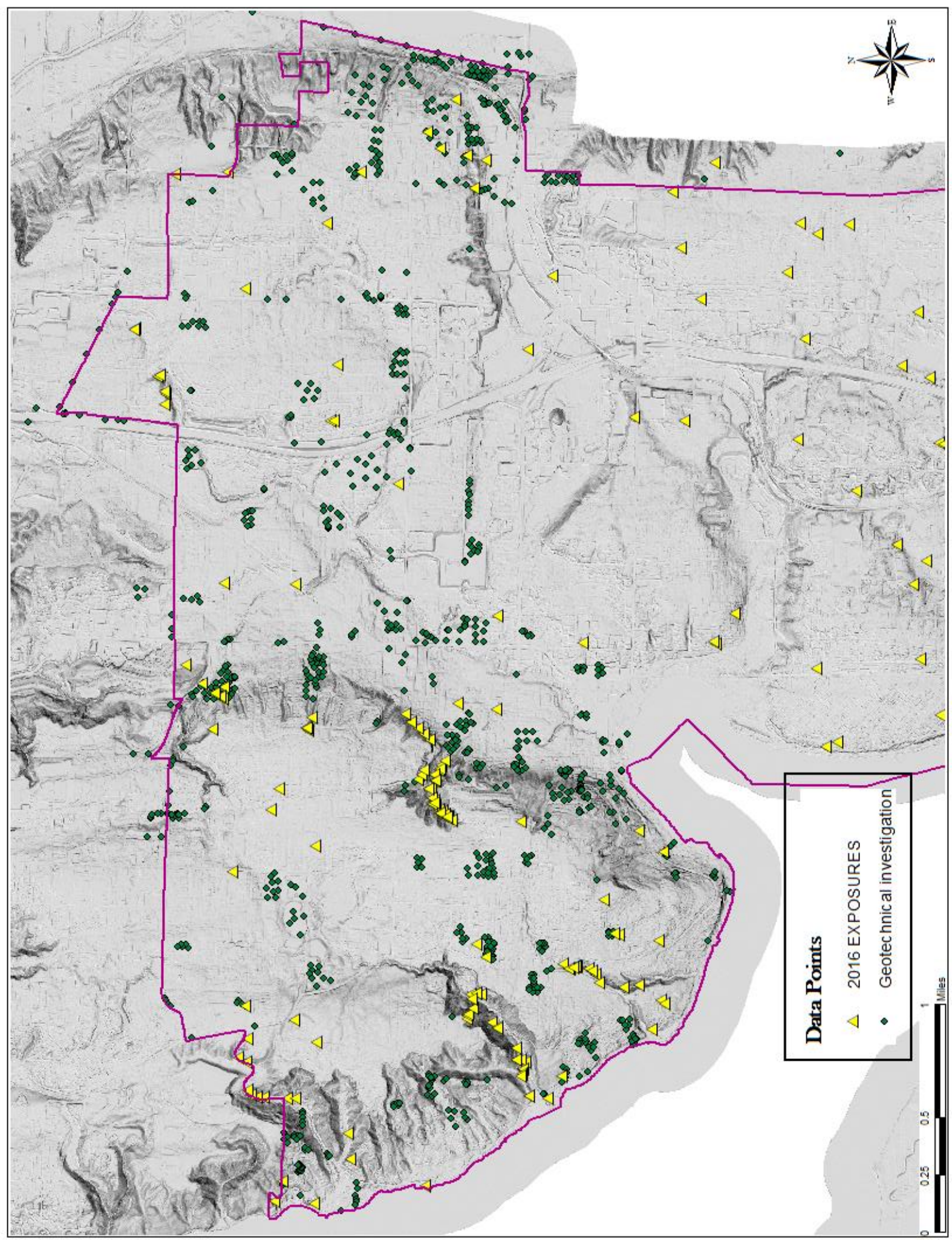

Figure 12: This map of the annexation area shows my field stations as yellow triangles and only interpreted geotechnical investigations as green dots. Labelling these points allows a user to see patterns of geologic units. 


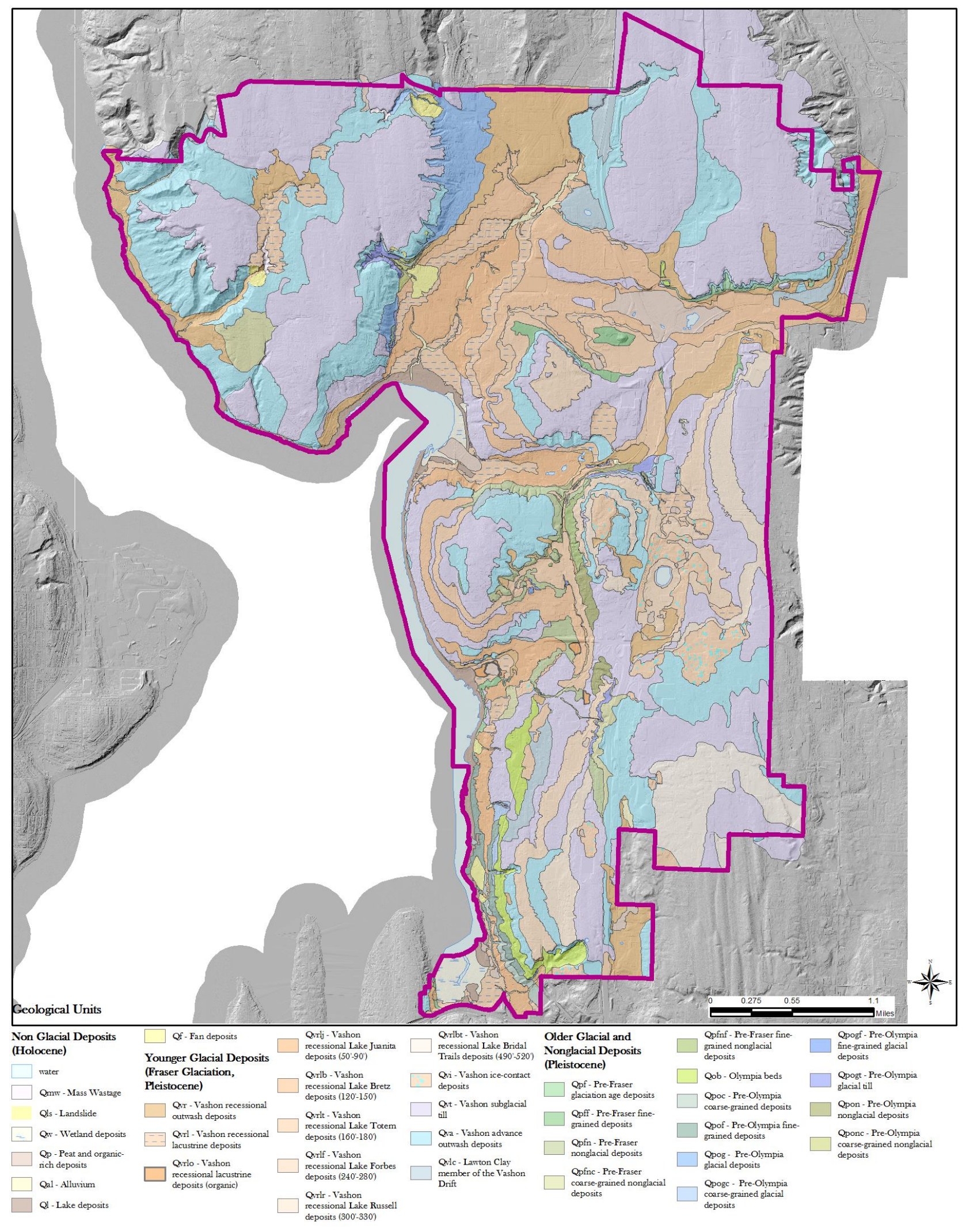

Figure 13: 1:12,000 scale Surficial geology map of Kirkland. 


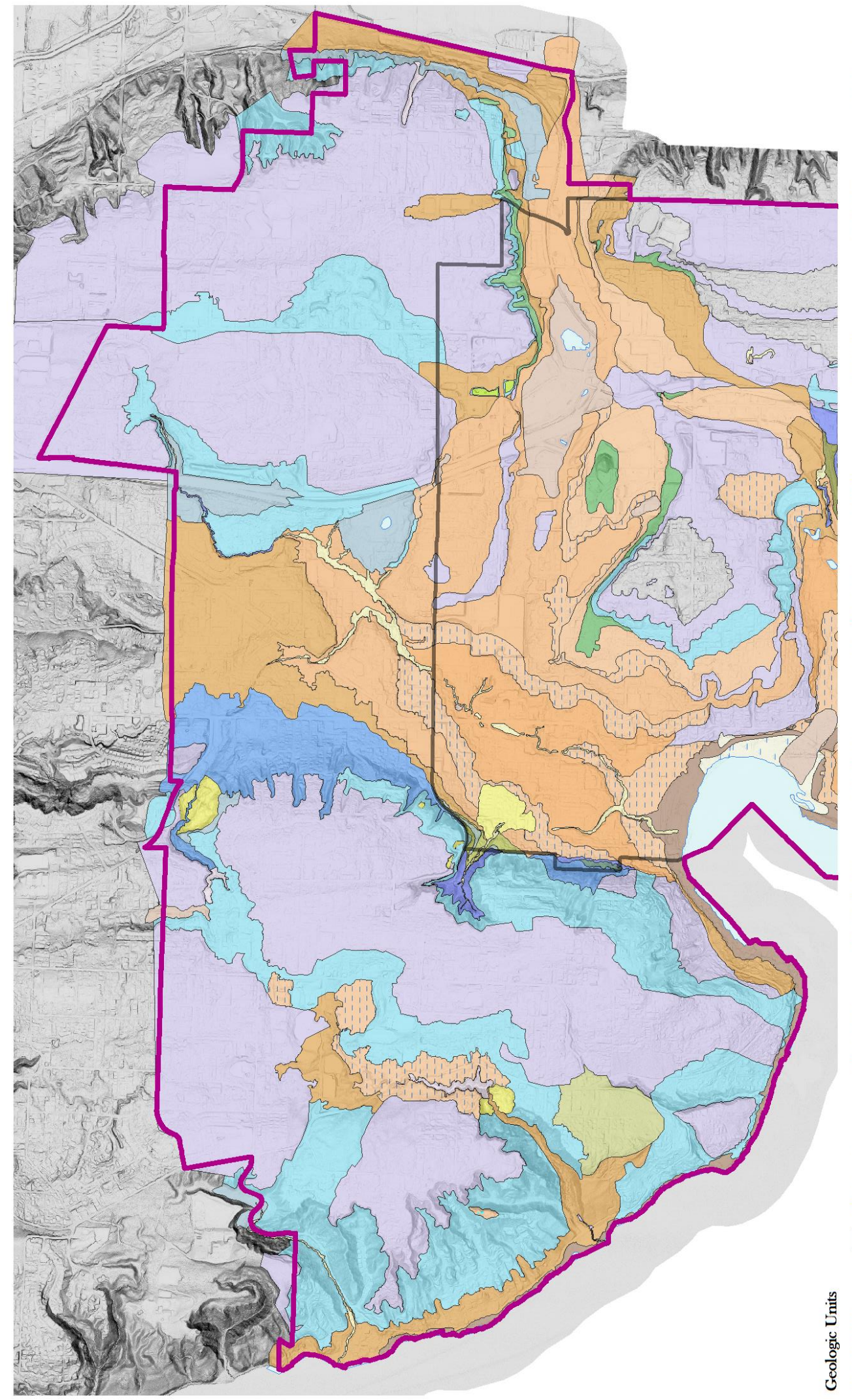

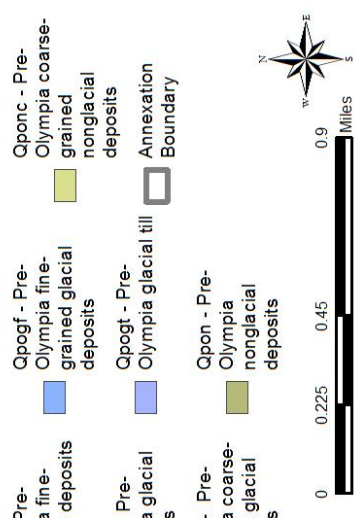

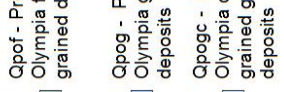
$\square \square \square$

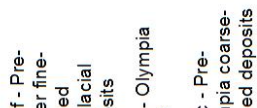

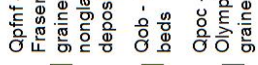

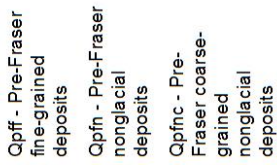

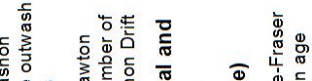

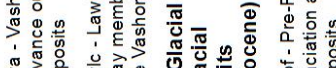

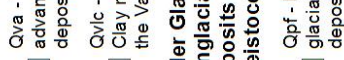

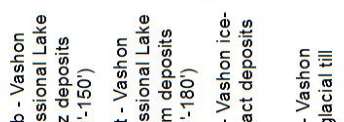

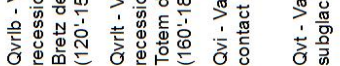
$\square \quad \square \quad \square \quad \square$

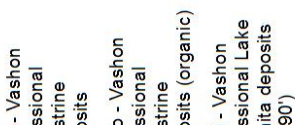

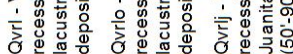
प $\square \square$

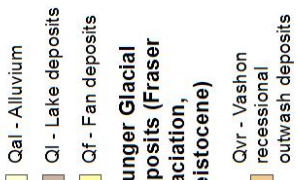

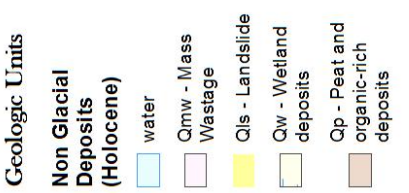

Figure 14: 1:12,000 scale surficial geology map of Kirkland's annexation area. 


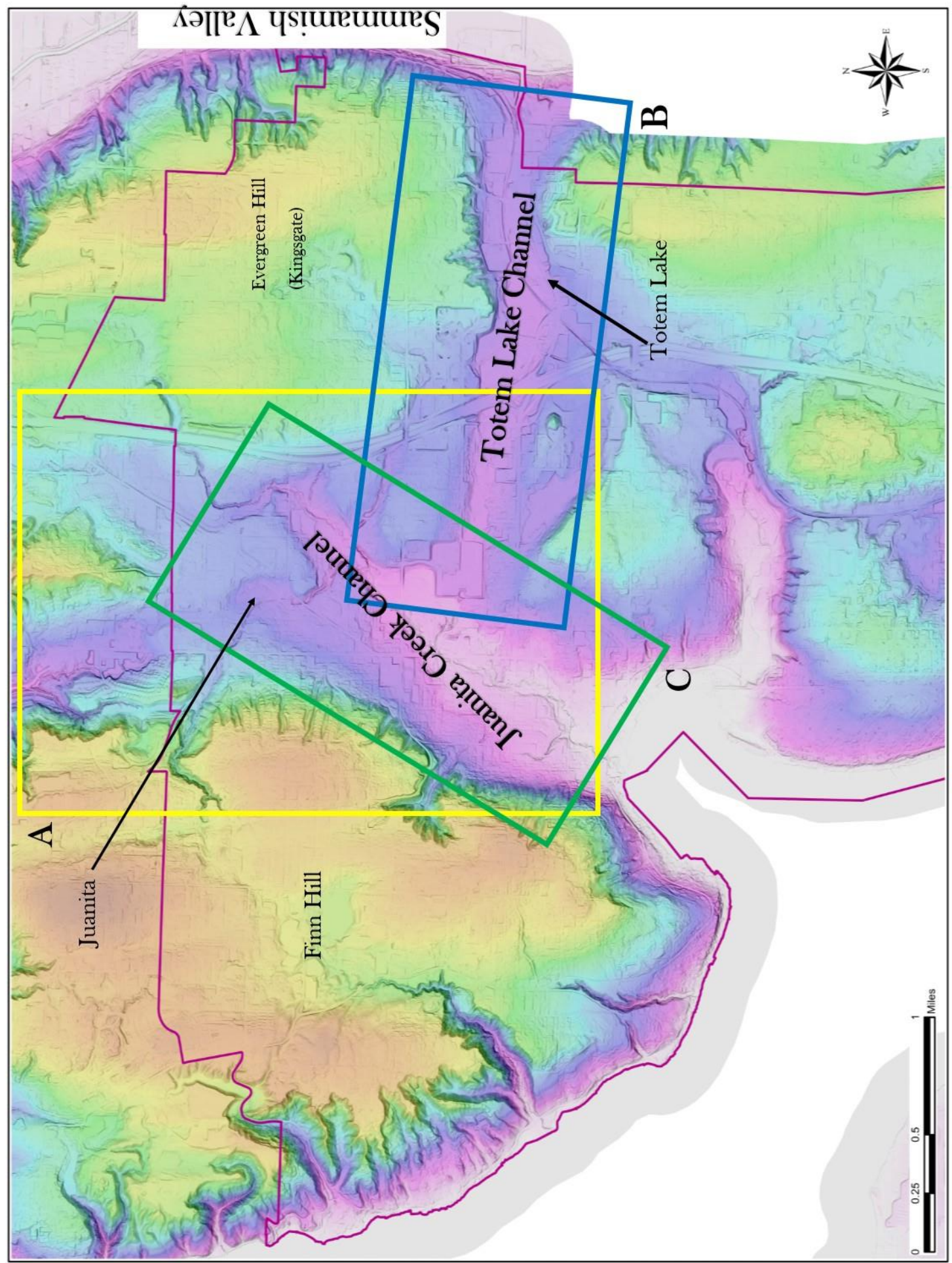

Figure 15: Image showing glacially formed broad recessional channels in the annexation area of Kirkland. Labeled rectangles enclose the channels. Also shown are neighborhood names. 


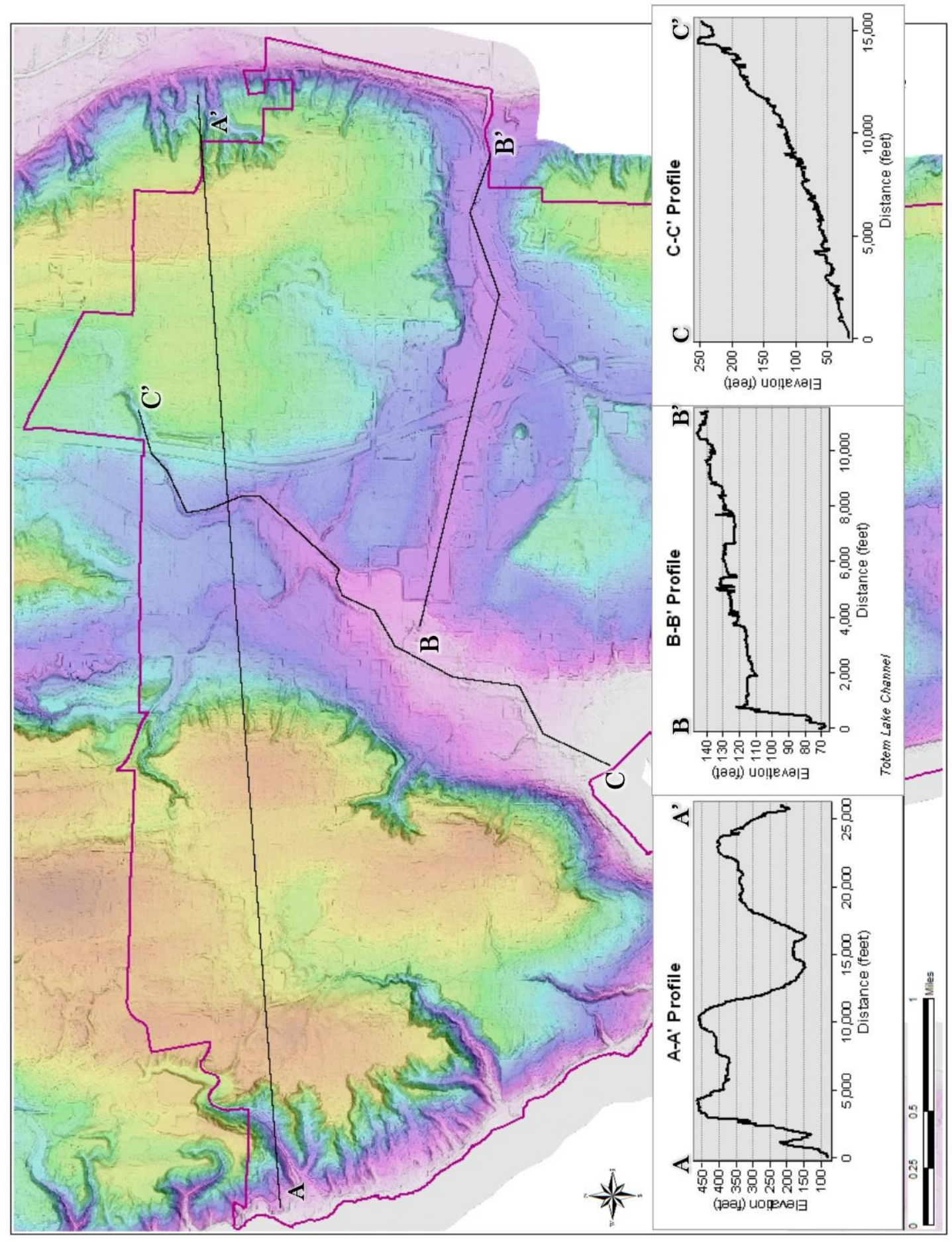

Figure 16: Ground surface profiles displaying elevation changes across the uplands and within the channels in the annexation area. 


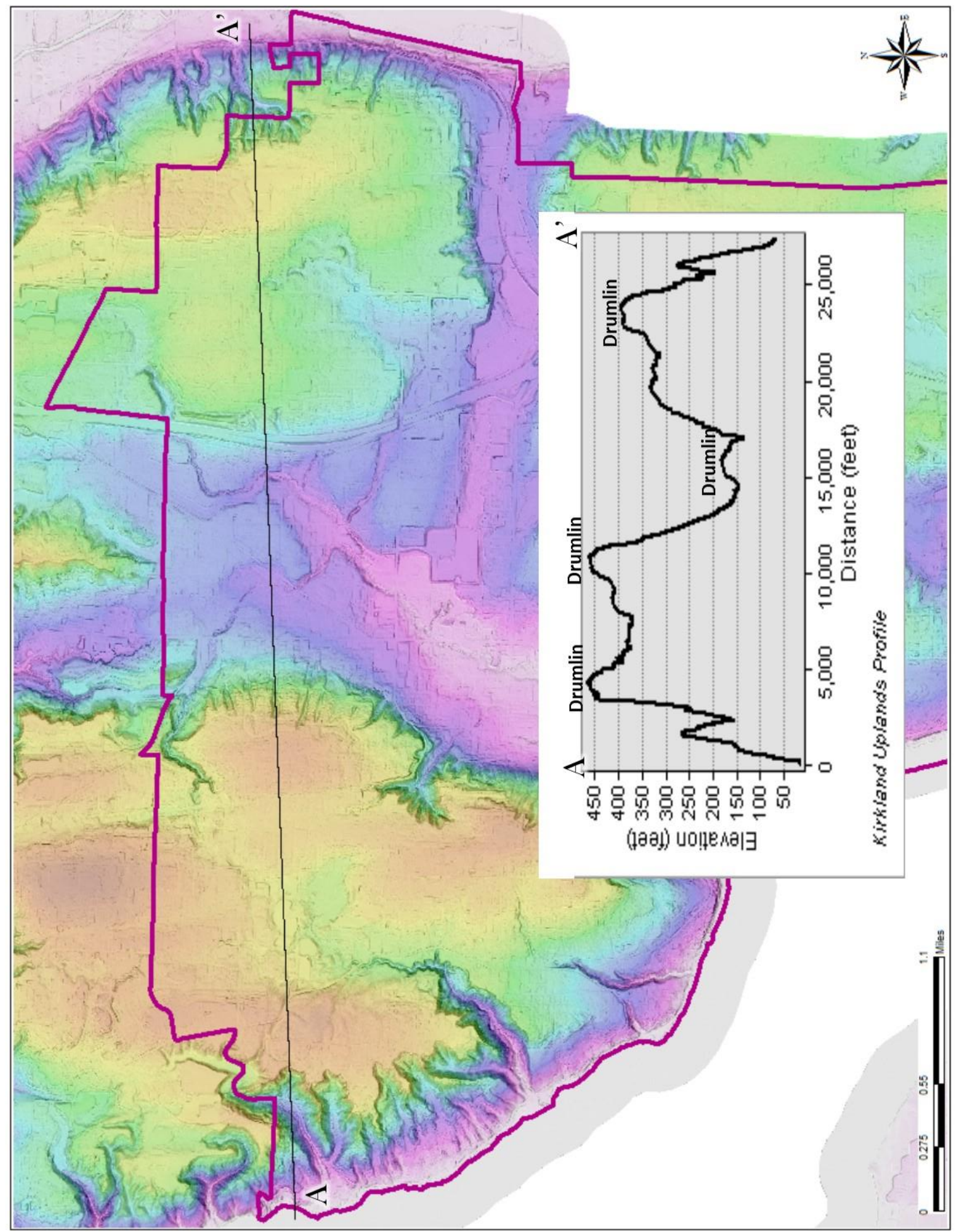

Figure 17: The ground surface elevation profile illustrates the locations of drumlins on the landscape. 


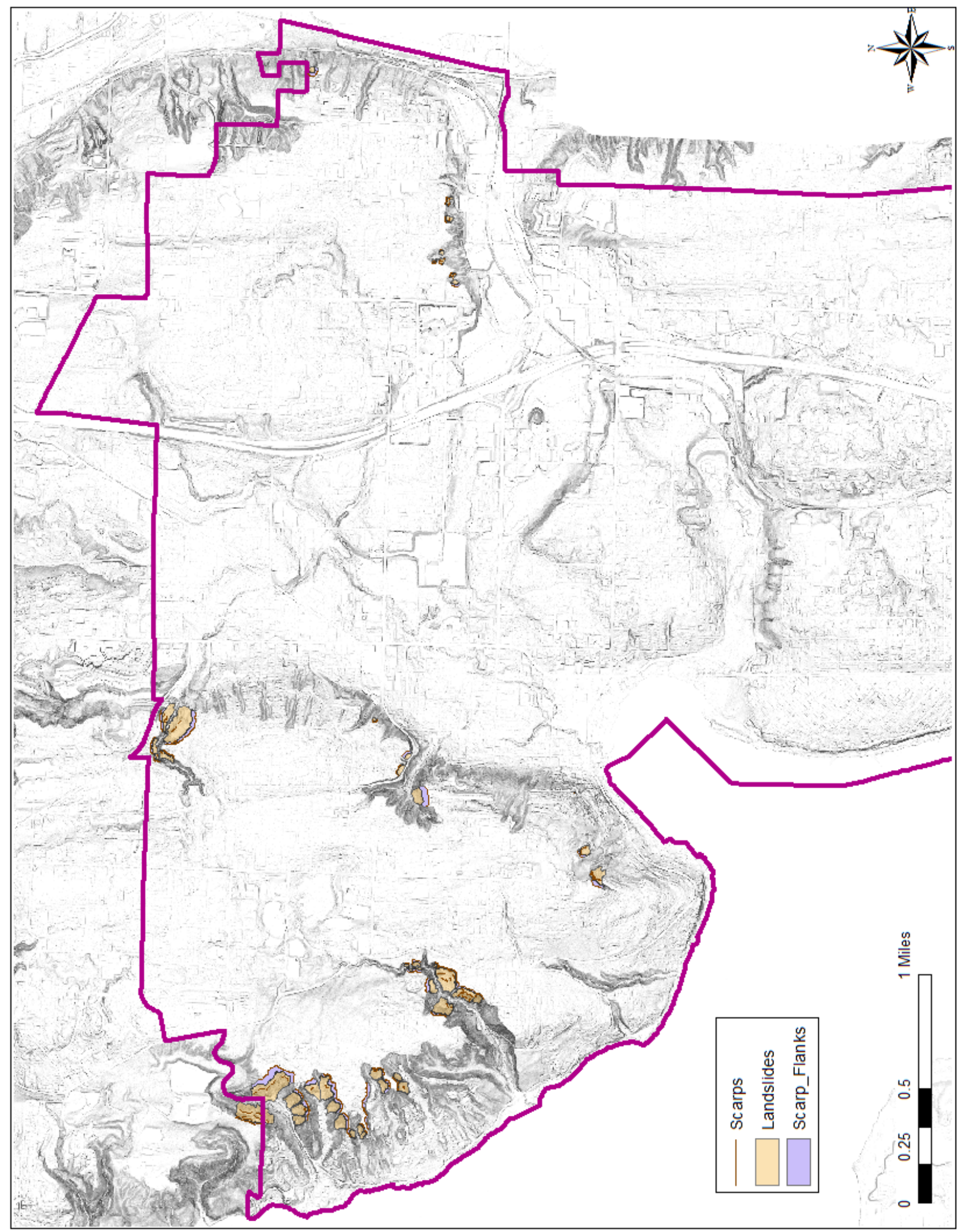

Figure 18: Percent slope map showing extent of landslide deposits (QIs and Qmw) in the annexation area. 


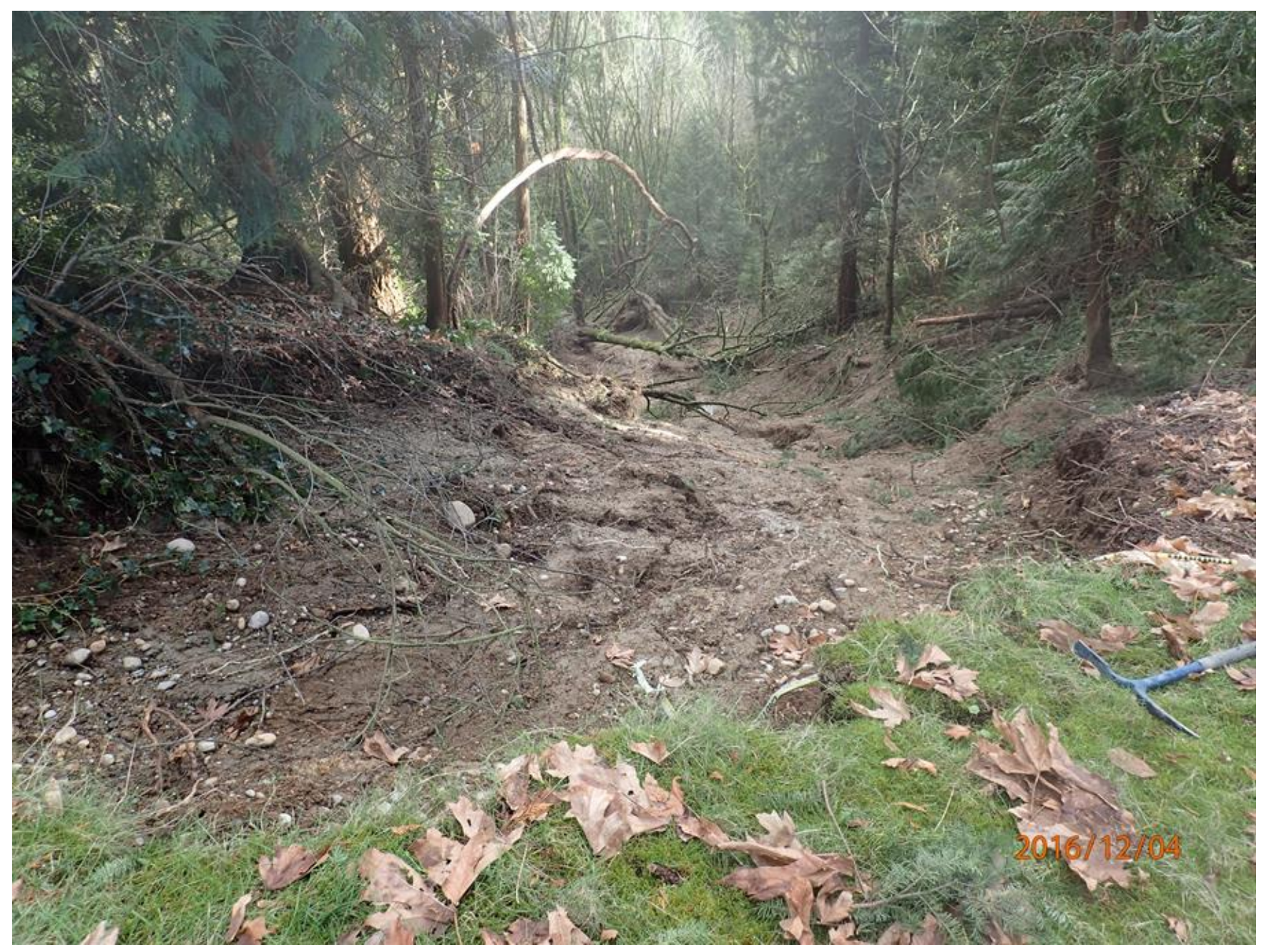

Figure 19: A photograph of the initiation point of a recent shallow landslide in the Finn Hill area. The slide uprooted and carried mature trees. It also ran up the opposite valley wall approximately 50 feet. The pick end of my geotool is fourteen inches long. See Figure 21 for slide location. The recent slide exists within an area of historic landslides. 


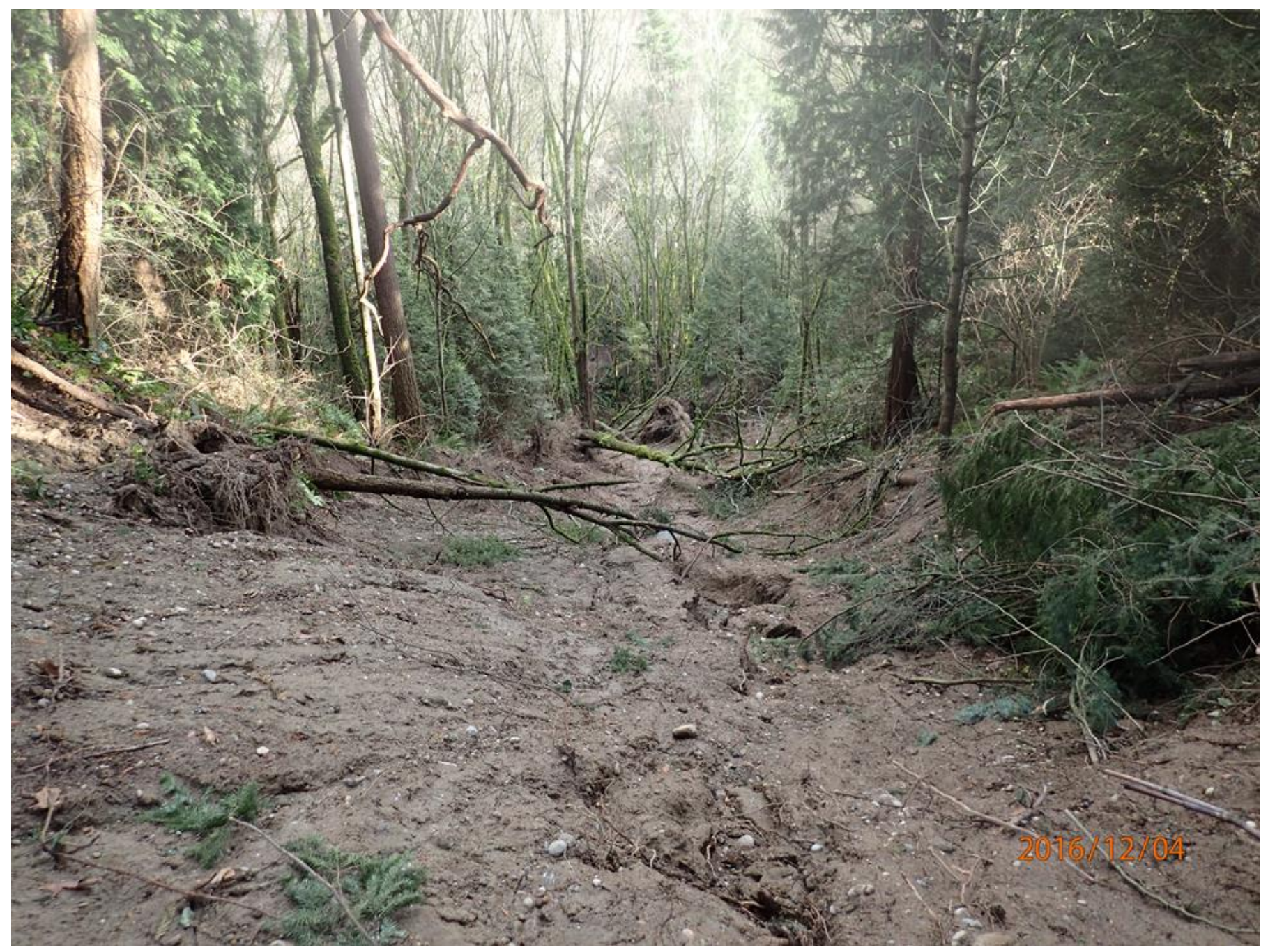

Figure 20: Photograph of scour and debris resulting from a shallow landslide that occurred in the Finn Hill area near the end of November. 


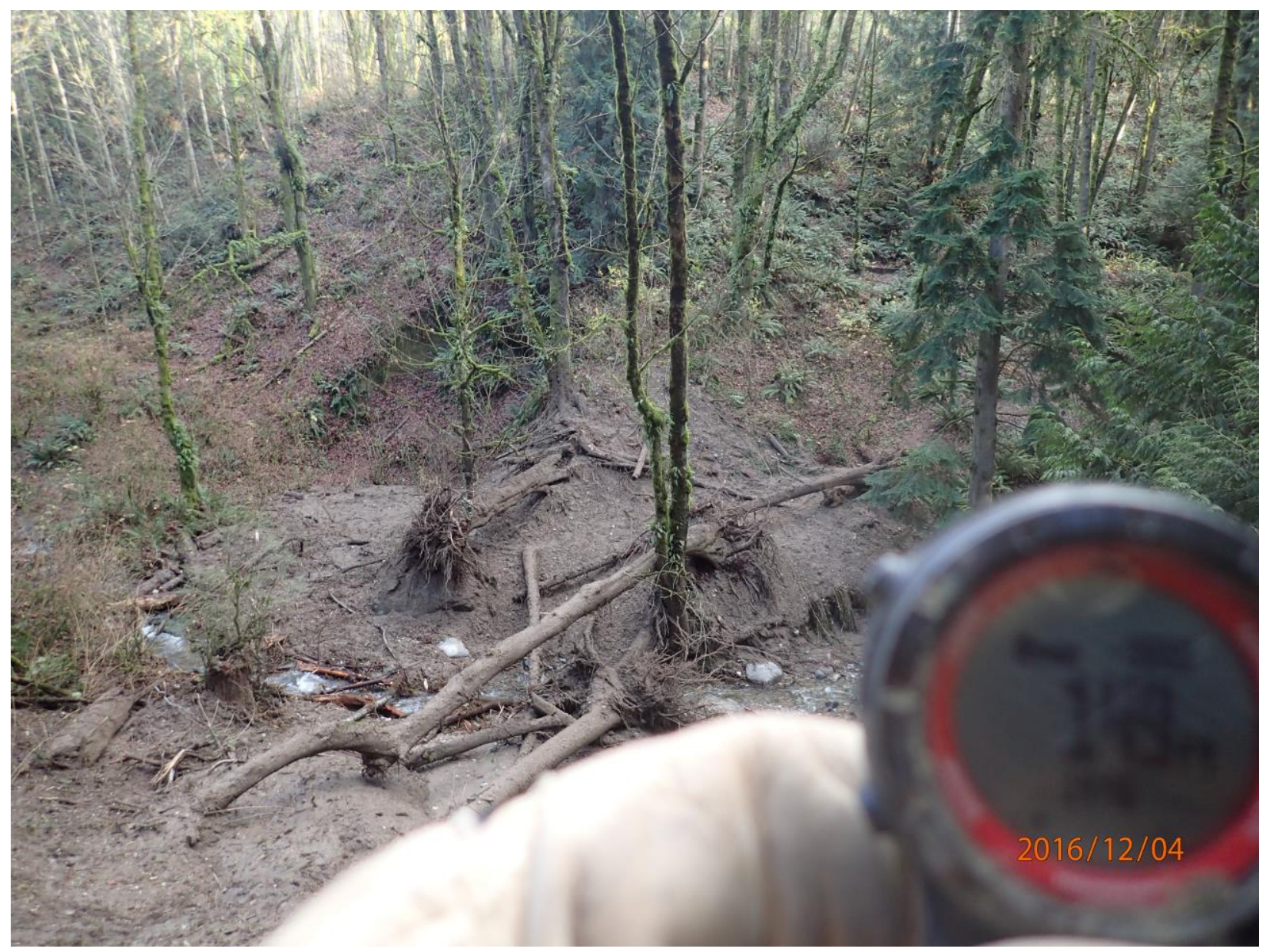

Figure 21: The landslide ran up the opposite valley wall approximately 50 feet. The altimeter reads approximately 150 feet above sea level (ASL) and the streambed reads approximately 100 feet ASL. Note the root balls on the opposite side of the stream. 


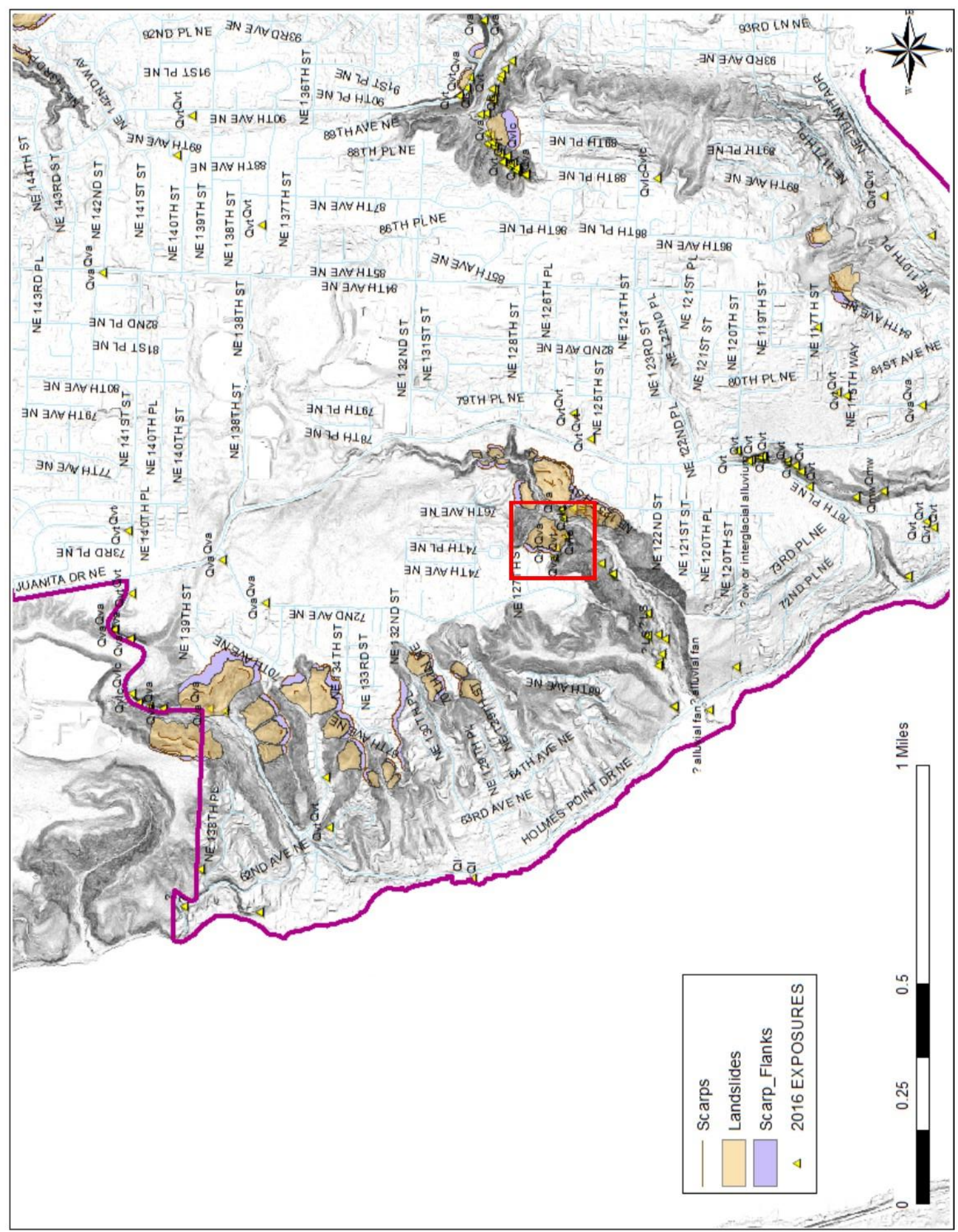

Figure 22: The red box illustrates the location of the November Finn Hill landslide. 


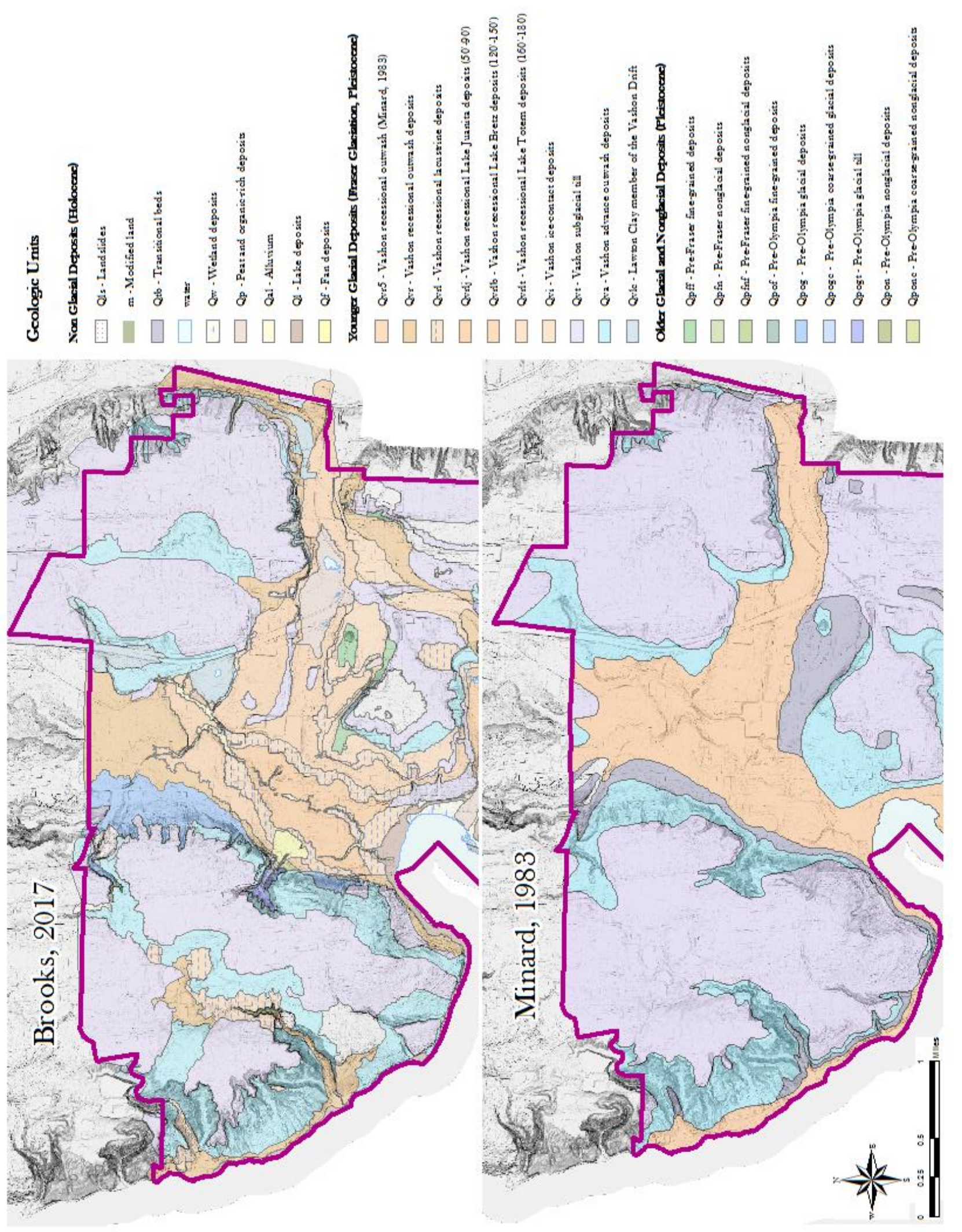

Figure 23: Comparing the two surficial geology maps, 2017 (top) and 1983 (bottom). 


\section{TABLES}

Table 1: Breakdown of Datapoints showing the data in the city vs. annexation area and the 2010 data and the current accumulated data.

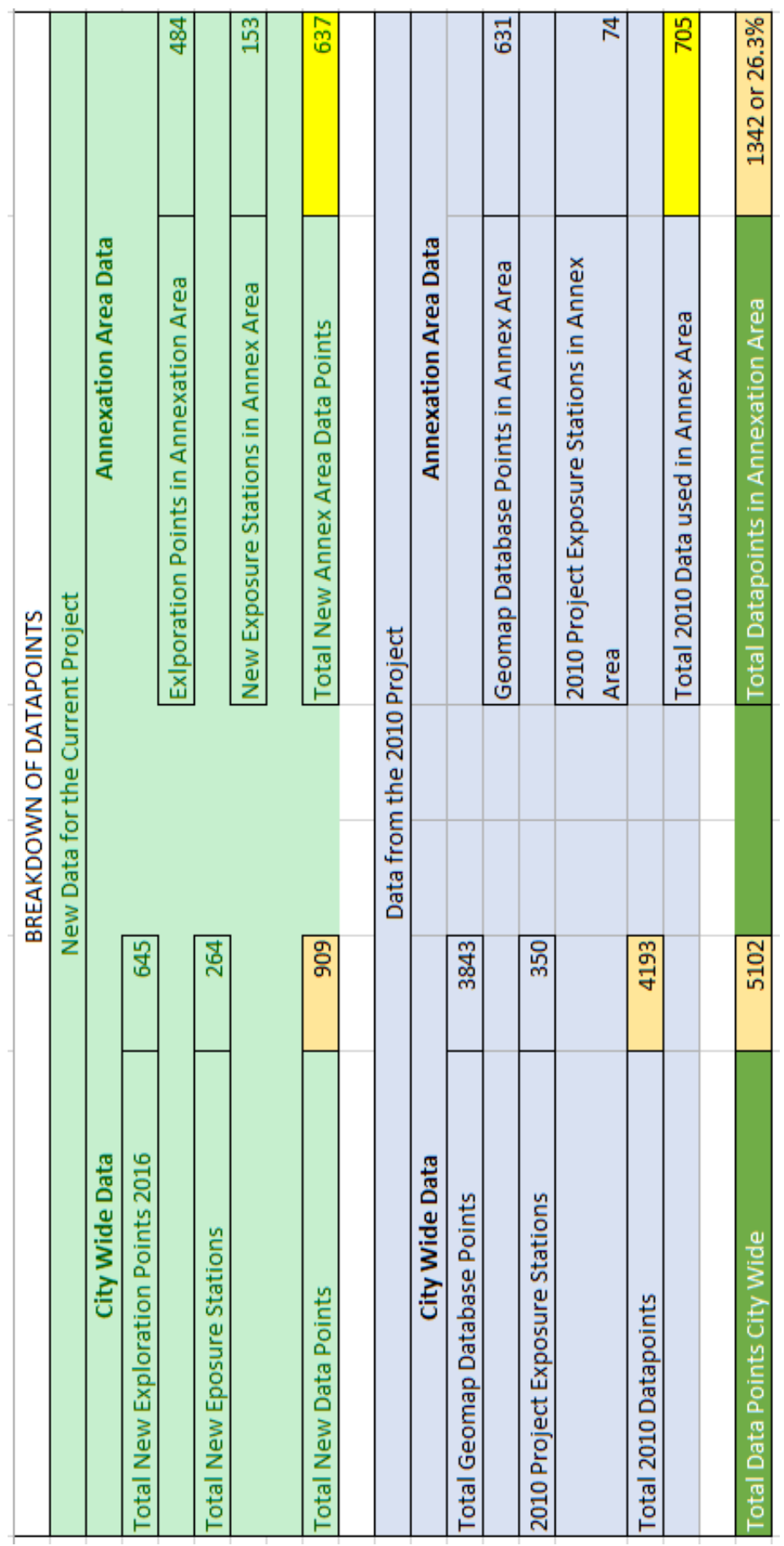


Table 2: Comparing the Area of Geologic Units of Minard 1983 and 2017 Kirkland Annexation Areas.

\begin{tabular}{|c|c|c|}
\hline & Minard 1983 & 2017 \\
\hline Geologic Units & Area (sq feet) & Area (sq feet) \\
\hline Q1s - Landslide Deposits & 188447.20 & 998164.48 \\
\hline Qoal - Older Alluvium (Holocene) & 1277541.99 & 0 \\
\hline Qob - Olympia Beds & 10175.59 & 102387.29 \\
\hline Qtb/Qvlc - Transitional Beds & 31798629.05 & 6046022.67 \\
\hline Qtu - Pre-Frasier Till & 827083.93 & 0 \\
\hline Qva - Advance Outwash & 53259548.28 & 53785814.69 \\
\hline Qvr - Vashon Recessional Outwash & 62442679.41 & 30024389.73 \\
\hline Qvt - Vashon Till & 274453284.97 & 140422978.82 \\
\hline Qyal - Younger Alluvium (Holocene) & 169237.25 & $\underline{0}$ \\
\hline Qal - Alluvium & 0 & 1653909.42 \\
\hline Qf - Fan Deposits & 0 & 874685.64 \\
\hline Q1s - Landslide Deposits & 188447.20 & 998164.48 \\
\hline Qmw - Mass Wastage & 0 & 513231.51 \\
\hline Qp - Peat & 0 & 5852204.33 \\
\hline Qpf - Pre-Fraser Glaciation Deposits & 0 & 759130.21 \\
\hline $\begin{array}{l}\text { Qpff - Fine-Grained Pre-Fraser Glaciation } \\
\text { Deposits }\end{array}$ & 0 & 1831644.23 \\
\hline $\begin{array}{l}\text { Qpfnc - Coarse-Grained Nonglacial } \\
\text { deposits }\end{array}$ & 0 & 2855097.93 \\
\hline Qpoc-Coarse-Grained Deposits & 0 & 111430.73 \\
\hline Qpof - Fine-Grained Deposits & 0 & 118950.60 \\
\hline Qpog - Glacial Deposits & 0 & 8600205.65 \\
\hline Qpogt - Till Deposits & 0 & 1183214.63 \\
\hline $\begin{array}{l}\text { Qponc - Coarse Grained Nonglacial } \\
\text { Deposits }\end{array}$ & 0 & 363924.27 \\
\hline Qvi - Ice-contact & 0 & 82800.80 \\
\hline Qvlc - Lawton Clay & 0 & 6046022.67 \\
\hline Qvrlb - Recessional Lake Bretz Deposits & 0 & 47240255.89 \\
\hline Qvrlf - Recessional Lake Forbes Deposits & 0 & 5684802.02 \\
\hline Qvrlj - Recessional Lake Juanita Deposits & 0 & 12940068.90 \\
\hline Qvrlr - Recessional Lake Russel Deposits & 0 & 6874216.33 \\
\hline Qvrlt - Recessional Lake Totem Deposits & 0 & 10165437.02 \\
\hline Qvrl - Recessional Lacustrine Deposits & 0 & 15428424.79 \\
\hline Qw - Wetlands & 0 & 957234.49 \\
\hline
\end{tabular}




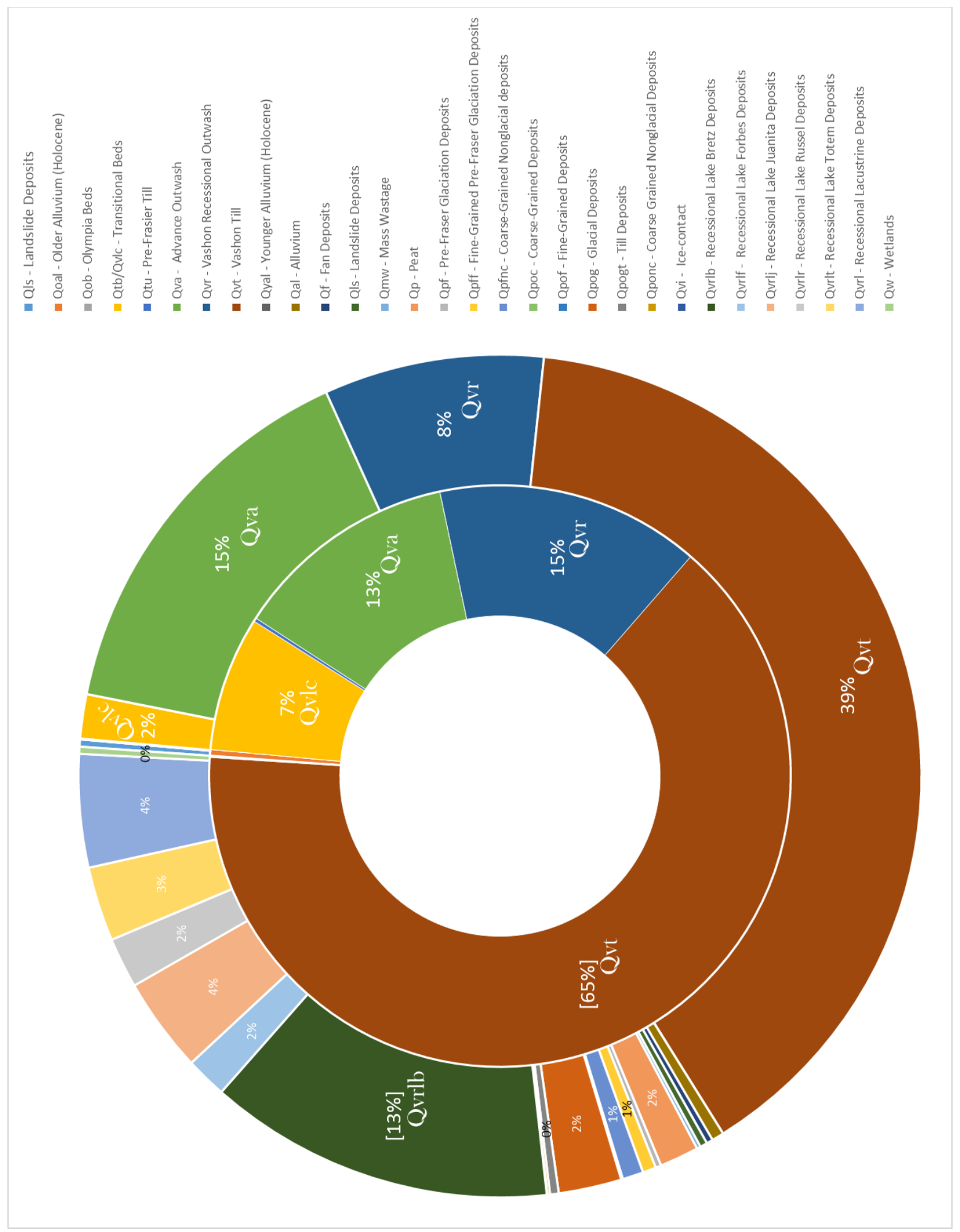

Chart 1: Comparison of Percent of Total Area of Geologic Units Between Minard 1983 (inner ring) and 2017 Kirkland Annexation Map (outer ring) 
Table 3: Description of map units in the Kirkland Annexation Area.

\begin{tabular}{|c|c|}
\hline \multicolumn{2}{|c|}{$\begin{array}{r}\text { DESCRIPTION OF MAP UNITS IN TH } \\
\text { ANNEXATION AREA }\end{array}$} \\
\hline \multicolumn{2}{|r|}{ Quaternary Sediments } \\
\hline \multicolumn{2}{|r|}{ NONGLACIAL DEPOSITS } \\
\hline \multirow[t]{2}{*}{ af } & Artificial Fill \\
\hline & $\begin{array}{l}\text { Sand, gravel, construction debris, garbage, concrete, asphalt and other } \\
\text { materials placed as a result of human activity. }\end{array}$ \\
\hline \multirow[t]{2}{*}{ Qmw } & Mass-wastage Deposits \\
\hline & Colluvium, slope wash, soil and landslide debris \\
\hline \multirow[t]{2}{*}{ Qls } & Landslide Deposits \\
\hline & $\begin{array}{c}\text { Often a chaotic mix of native materials moved en masse downslope } \\
\text { by gravity. May be internally coherent as a block mass of material } \\
\text { moved. }\end{array}$ \\
\hline \multirow[t]{2}{*}{ Qw } & Wetland Deposit \\
\hline & $\begin{array}{c}\text { Organic rich sediment, peat, and fine-grained material, poorly drained } \\
\text { and intermittently wet. }\end{array}$ \\
\hline \multirow[t]{2}{*}{ Qal } & Alluvium \\
\hline & Sand, silt and gravel deposited by moving water, ie. streams and rivers. \\
\hline \multirow[t]{2}{*}{$\mathrm{Ql}$} & Lake Deposit \\
\hline & th local sand layers, peat and organic layers. \\
\hline
\end{tabular}

\begin{tabular}{|l|l|}
\hline \multicolumn{2}{|c|}{ VASHON GLACIAL DEPOSITS } \\
\hline Qvr & Vashon Recessional Outwash Deposits \\
\cline { 2 - 3 } & $\begin{array}{l}\text { Loose to dense, moderately sorted to well-sorted stratified sand and } \\
\text { gravel. Typically located in recessional channels. May include thin } \\
\text { lag on glacial till in uplands. }\end{array}$ \\
\cline { 2 - 3 } & $\begin{array}{l}\text { Vushon Recessional Lacustrine Deposits } \\
\text { Very soft to stiff, laminated silt and clay with local sand lenses, peat } \\
\text { and organics. Deposited in slow-flowing water or recessional lakes. }\end{array}$
\end{tabular}




\begin{tabular}{|c|c|}
\hline \multirow[t]{2}{*}{ Qvrlt } & Vashon Recessional Lake Totem Deposits \\
\hline & $\begin{array}{l}\text { Laminated to interbedded, silt and silty fine sand with some less clayey } \\
\text { silt deposited in recessional lakes and slow moving water. }\end{array}$ \\
\hline \multirow[t]{2}{*}{ Qvrlb } & Vashon Recessional Lake Bretz Deposits \\
\hline & $\begin{array}{l}\text { Thin laminated to interbedded, silt and silty fine sand deposited in } \\
\text { slow-flowing water and ephemeral lakes. Present in flat lying areas } \\
\text { around elevations } 120 \text { to } 150 \text { feet. Soft and loose. }\end{array}$ \\
\hline \multirow[t]{2}{*}{ Qvt } & Vashon till \\
\hline & $\begin{array}{l}\text { Dense to very dense compact unsorted and unstratified diamict of silt, } \\
\text { sand, and subrounded to rounded gravel. Cobbles and boulders are } \\
\text { scattered throughout the deposit. Light grey in color. Generally } \\
\text { drapes topography. Thickness varies from less than } 1 \text { meter to nearly } \\
5 \text { meters. Locally described as "hardpan" due to its concrete-like } \\
\text { characteristics. Weathering is confined to the upper layers. }\end{array}$ \\
\hline \multirow[t]{2}{*}{ Qva } & Vashon Advance Outwash Deposits \\
\hline & $\begin{array}{l}\text { Well-sorted sand and gravel. Deposited by streams emanating trom } \\
\text { the front of the advancing ice sheet. Local deposits <30m thick but } \\
\text { often pinch out on slopes. Grades downward into Qvlc. Bedding } \\
\text { structures include crossbedding, scouring, and channels. The } \\
\text { outwash was overridden by advancing ice making it dense to very } \\
\text { dense. }\end{array}$ \\
\hline \multirow[t]{2}{*}{ Qvlc } & Vashon Lawton Clay \\
\hline & $\begin{array}{l}\text { Very stiff to hard, grey laminated silt, clayey silt, to silty clay. Local } \\
\text { sand lenses occur near contact with Qva. Occasional dropstones are } \\
\text { present. Some deposits reach approximately } 4 \text { meters thickness. }\end{array}$ \\
\hline \multirow[t]{2}{*}{ Qvi } & Vashon Ice Contact \\
\hline & $\begin{array}{l}\text { Horzontally bedded to steeply dipping till and outwash. May not have } \\
\text { been glacially overridden. }\end{array}$ \\
\hline
\end{tabular}




\begin{tabular}{|c|c|c|}
\hline \multicolumn{3}{|c|}{$\begin{array}{l}\text { PRE-VASHON GLACIAL and NONGLACIAL } \\
\text { DEPOSITS }\end{array}$} \\
\hline \multirow[t]{2}{*}{ Qpfnc } & Course-Grained Nonglacial Deposits & \\
\hline & $\begin{array}{l}\text { Very dense, sand and gravel with sc } \\
\text { Moderately oxidized and iron }\end{array}$ & $\begin{array}{l}\text { me silt and peat layers. } \\
\text { l-oxide cemented. }\end{array}$ \\
\hline \multirow[t]{2}{*}{ Qpog } & Glacial Deposits & \\
\hline & Silt, sand, gravel and till of glacial origin. & Underlies Vashon deposits. \\
\hline \multirow[t]{2}{*}{ Qpogt } & Till Deposits & \\
\hline & $\begin{array}{l}\text { Very dense and hard till thick enough t } \\
\text { exposed in erosional gullies stratigraphic } \\
\text { till. }\end{array}$ & $\begin{array}{l}\text { o show at map scale. Often } \\
\text { ally below identified Vashon }\end{array}$ \\
\hline
\end{tabular}

